\title{
National Ignition Facility Risk Management Plan Revision 2
}

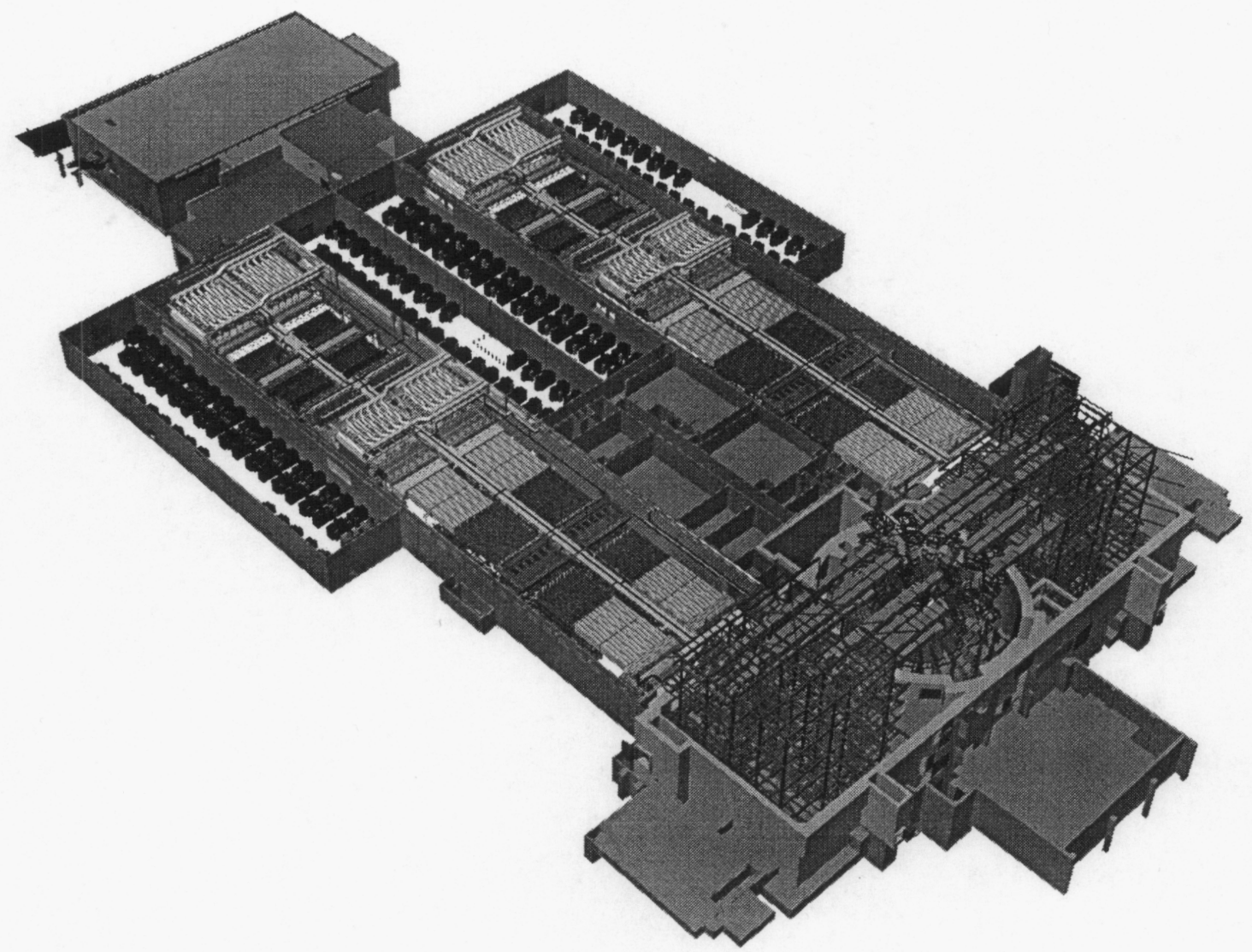

June 2002

Lawrence Livermore National Laboratory 7000 East Avenue Livermore, CA 94550 
DISCLAIMER

This document was prepared as an account of work sponsored by an agency of the United States Government. Neither the United States Government nor the University of California nor any of their employees, makes any warranty, express or implied, or assumes any legal liability or responsibility for the accuracy, completeness, or usefulness of any information, apparatus, product, or process disclosed, or represents that its use would not infringe privately owned rights. Reference herein to any specific commercial products, process, or service by trade name, trademark, manufacturer, or otherwise, does not necessarily constitute or imply its endorsement, recommendation, or favoring by the United States Government or the University of California. The views and opinions of authors expressed herein do not necessarily state or reflect those of the United States Government or the University of California, and shall not be used for advertising or product endorsement purposes.

This report has been reproduced directly from the best available copy.

Available to DOE and DOE contractors from the

Office of Scientific and Technical Information

P.O. Box 62, Oak Ridge, TN 37831

Prices available from (615) 576-8401, FTS 626-8401

Available to the public from the

National Technical Information Service

U.S. Department of Commerce

5285 Port Royal Rd.

Springfield, VA 22161

Work performed under the auspices of the U.S. Department of Energy by Lawrence Livermore National Laboratory under Contract W-7405-Eng-48. 


\title{
NIF Risk Management Plan Rev. 2
}

\author{
June 2002
}

Prepared by: $\frac{\text { Aandiag Brere ton }}{\text { Sandra J. Brereton }}$

NIF Risk Management Team:

Jeff Atherton Tom Parham

Jack Campbell David Rardin

Clarence Dun Greg Tietbohl

Chris Haynam Paul Weber

Steve Johnson Jon Yatabe

Frank Papp

Approved by: $\frac{\text { Edward I. Moses }}{\text { NIF Project Manager }}$ 


\section{Contents}

1.0 Introduction

2.0 Background/Mission of the NIF Project............................................................4

2.1 Stockpile Stewardship and Management..................................................4

2.2 Inertial Fusion Energy ..............................................................................4

2.3 Science, Technology, and Other Applications ...........................................

3.0 Performance, ES\&H, Cost and Schedule Basis for Risk Assessment...............6

4.0 Risk Identification ............................................................................................6

5.0 Risk Assessment and Management Measures...................................................12

5.1 Risk Assessment Methodology ……………………..................................12

5.2 Risk Assessment Results ..........................................................................15

5.3 Risk Management and Implementation ……………..................................17

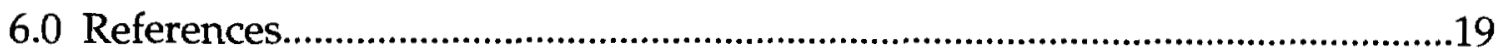

APPENDIX A, Justification of Consequences and Likelihoods ..............................22

APPENDIX B, Initial $(2 / 97,4 / 98)$ NIF Risk Elements ...........................................32 


\subsection{Introduction}

The National Ignition Facility (NIF) Risk Management Plan (LLNL, 1997a)) was originally prepared in 1997 in accordance with the Department of Energy (DOE) Life Cycle Asset Management Good Practice Guide (DOE, 1996a) and supported NIF Critical Decision 3, approval to initiate construction (DOE, 1997a). The plan was updated in 1998 to reflect realized risks such as the finding and successful clean up of polychlorinated biphenyl (PCB)-filled electrical capacitors at the NIF excavation during initial construction and the litigation of the Programmatic Environmental Impact Statement for Stockpile Stewardship (DOE, 1996b) by a group of non-governmental organizations led by the Natural Resources Defense Council.

The current update of the Risk Management Plan brings it into compliance with the applicable DOE Orders and Standards and addresses new risks, such as assuring safety during the period when construction, special equipment installation, and commissioning are occurring simultaneously at the NIF site, and the extensive use of models to manage technical performance risk. The objectives of the updated plan are to:

1. Identify the risks to the completion of the Project in terms of meeting performance and regulatory requirements, $\mathrm{ES} \& \mathrm{H}$, cost, and schedule

2. Assess or the risks in terms of likelihood of occurrence and their impact potential relative to technical performance, ES\&H, costs, and schedule

3. Address suitable risk mitigation measures for each identified risk.

The process used in developing this revision was to form a new Risk Assessment Team to augment the original risk assessment documented in the first two versions of the plan (LLNL, 1997a; LLNL, 1998a). The new team consisted of the System Engineering Manager, Risk Step Manager, Project Assurance Manager, Operations Manager, Production Manager, Project Control Manager, Beampath Infrastructure Associate Project Manger, Line Replaceable Unit Deputy Associate Program Manager, Laser Materials and Optics Associate Project Manager, Quality Assurance Manager, and ES\&H Assurance Manager. The team was led by the ES\&H Assurance Manager. These people are familiar with the risk basis documents and contributed to the identification of the key risk elements. Risk elements were reviewed, and likelihoods, consequences, and risk levels were assigned. The methodology is described in section 5.1. After assessing the risks, risk management measures were developed. This document presents the results of the consolidated assessment of the team.

The revised plan represents a top-level view of the major Project risks. It forms the basis from which the System Engineering organization can develop a more detailed breakdown of risk elements to evaluate and provide recommended mitigation or controls to manage the risks. As appropriate, recommended mitigations would be reviewed through the change control process before being formally adopted. 
The documents that form the basis for this risk assessment are as follows:

1. Final Programmatic Environmental Impact Statement for Stockpile Stewardship and Management (DOE, 1996b) and Record of Decision (DOE, 1996c).

2. Supplemental Environmental Impact Statement (SEIS) (DOE, 2001a).

3. Preliminary Hazards Analysis (Brereton, 1993).

4. Fire Hazards Analysis (Jensen, 1997).

5. Preliminary Safety Analysis Report (LLNL, 1996a).

6. Preliminary Draft Final Safety Analysis Report (LLNL, 1999).

7. Reliability, Availability and Maintainability Plan (LLNL, 1997b).

8. Radiation Protection Evaluation (Singh, 1993).

9. Primary Criteria and Functional Requirements (LLNL, 1997c).

10. Project Execution Plan (DOE, 2001b).

11. NIF Project Site Safety Program (LLNL, 2001a).

12. Infrastructure Health and Safety Plan, Jacobs Facilities Inc. (Jacobs, 2000).

13. Title II Design Media.

14. Project Data Sheet (LLNL, 1997f).

15. Supplement analysis for the Use of subgram quantities of Uranium-238, depleted uranium (DOE, 1998).

16. Quality Assurance Program Plan (LLNL, 2002a).

18. Mitigation Action Plan (DOE, 1997b).

19. NIF Programs Training Plan (LLNL, 2002b).

20. Project Control Procedure No. 1.6, Assignment of Quality Assurance Levels (LLNL, 1997g)

21. Procedure 1.2, Cost Estimating (LLNL, 2001b)

22. Procedure 1.3, Schedule Preparation, Statusing and Revision (LLNL, 2002c).

23. Procedure 1.12, Project Performance Measurement Using Earned Value (LLNL, 2002d).

24. Procedure 5.1, Engineering Design Reviews (LLNL, 2000a)

25. Procedure 7.1, Supplier Qualification (LLNL, 2000b) 
26. Procedure 7.3, Vendor Surveillance (LLNL, 2000c)

27. Procedure 7.4, Procurement Planning, Scheduling, Review and Approval (LLNL, 2001c)

28. Procedure 9.3, Safety and Performance Review Board, Management Prestart Reviews, and Working Group Reviews (LLNL, 2002e).

29. Procedure 8.1, Suspect/Counterfeit Items Detection and Prevention (LLNL, 2001d). 


\subsection{Background/Mission of the NIF Project}

The National Ignition Facility DOE Justification of Mission Need (LLNL, 1994) approved by the Secretary of Energy defines the specific mission of the NIF Project. The most immediate application of the NIF will be to provide nuclear weapons-related physics data since many high-energy-density physics phenomena that will occur during NIF experiments are relevant and similar to those occurring in nuclear weapons. With a comprehensive test ban, the NIF will also provide an important capability for weapons-effects simulations. Under the cessation of underground nuclear testing, the NIF, along with numerical simulations and other above ground experimental facilities, will provide the critical data that will allow the United States to maintain its technical capabilities in nuclear weapons. As a secondary objective, the NIF will advance our understanding of inertial confinement fusion and help to assess its potential as an energy source. Achieving fusion ignition in the NIF will advance both defense and energy objectives.

In affirming the Project's Critical Decision 2, Approval of New Start, and Critical Decision 3, Approval to Initiate Construction, the Secretary of Energy verified the mission need and emphasized that the NIF has the potential to contribute significantly to the following DOE mission areas:

- Stockpile Stewardship and Management;

- Inertial Fusion Energy;

- Science, Technology, and Other Applications.

\subsection{Stockpile Stewardship and Management}

In the absence of underground nuclear tests, the NIF will be a critical tool for the DOE science-based Stockpile Stewardship and Management Program. It will help to maintain the continued reliability and effectiveness of the stockpile by creating experimental conditions approaching those of nuclear weapons. In particular, the NIF's experimental capability will allow nuclear weapons scientists to assess stockpile problems, verify computational tools, test for nuclear weapons effects, and increase their understanding of weapons physics.

\subsection{Inertial Fusion Energy}

The NIF will represent the scientific culmination of research on inertial confinement fusion (ICF). In ICF, laser beams or particle beams are focused on targets containing fusion fuel, a mixture of deuterium and tritium, causing them to implode, creating the 
high temperatures and pressures necessary for these targets to burn. With the NIF, scientists plan to achieve ignition (self-heating of the fuel) and energy gain (more fusion energy produced than laser energy deposited) in the laboratory for the first time.

\subsection{Science, Technology, and Other Applications}

The NIF will attract world-class scientists and engineers to work on science of national importance. The ability to create experimental conditions similar to those found at the center of the Sun and the stars would accelerate progress in basic sciences, such as stellar physics and cosmology. As the world's largest precision optical instrument, the Project is spurring industrial capabilities, technologies, and commercial applications. 


\subsection{Performance, ES\&H, Cost and Schedule Basis for Risk Assessment}

The NIF performance, cost, and schedule baselines are described in the Project Execution Plan (DOE, 2001b), which was approved by the Assistant Secretary for Defense Programs. The Project Execution Plan also describes the process by which baseline changes are approved. The ES\&H envelope is described in the Final PEIS for Stockpile Stewardship and Management (DOE, 1996b) (mitigation measures in the Mitigation Action Plan (DOE, 1997b), the NIF Preliminary Safety Analysis Report (LLNL, 1996a), the Preliminary Draft of the Final Safety Analysis Report (Brereton, 1999), and the Quality Assurance Program Plan (LLNL, 2002a).

\subsection{Risk Identification}

The risk elements identified by the assessment team are listed in Table 1 and summarized below. The table provides the likelihood or probability of occurrence of each element; the performance, ES\&H, cost, and schedule impacts; and an estimate of the bounding risk. The items are listed and briefly discussed here. Risk elements that the team agreed presented negligible risks were prescreened and removed from further discussion (e.g., minor worker injuries during construction).

1. Risk of not getting the requested Congressional authorization and appropriation. This is possible for any Strategic Initiative due to the magnitude of the budget and the length of time over which it occurs. In FY1996 and FY1997, Congress provided the requested appropriations for NIF. In FY1998, Congressional authorization was less than requested, which caused a delay in NIF schedule and a commensurate cost increase. In FY1999 and FY2000, Congress provided the requested appropriations of NIF. In FY2001, the project was re-baselined which increased the schedule completion to FY2008 and established a new Total Project Cost (TPC) with a revised out year funding profile. The requested FY2001 rebaselined funding request was reduced by congress by $\$ 12 \mathrm{M}$ which delayed the activities to be accomplished in that year but did not impact the project completion date. The FY2002 appropriation was as requested. Timely congressional support at the requested amount is essential to maintain the project baseline cost and schedule.

2. Risk of delay in obtaining environmental permits that constrain the start of construction and operation no longer exists. The Record of Decision (a level 0 milestone) completing the National Environmental Policy Act (NEPA) determination was received on December 19, 1998. This was three months later than the expected date contained in the baseline schedule. Environmental 
permit applications were submitted immediately after the Record of Decision (ROD) (DOE, 1996c). Permits were granted without affecting the critical path schedule. Permits required for NIF operatio f l luding wipe cleaning and boiler permits, have already been obt 17 mately, the NIF Project site will transition from its own ar Plan (SWPPP) into the LLNL site-wide SW 1 . This should be accomplished without complication.

3. Risk of a successful legal challenge of the PEIS on Stockpile Stewardship and Management was successfully resolyed 2001. The Natural Resources Defense Council and 38 other organit $1 \mathrm{~d}$ a lawsuit against the PEIS for Stockpile Stewardship an Nar in 1997. This was successfully resolved in 2001, with th 1 plet on of a Supplemental Environmental Impact Statement.

4. Risk of Finding Paleontological Finds (e.g., animal fossils) or Cultural Resources (e.g., archeological artifacts) no longer exists. During the excavation of NIF, fossilized animal bones,wep found at several locations on the site. This resulted in minor delay 10 . 10 permitting by the Department of Interior, ic date, no cultural resourc Wuding archeological artifacts) have been identified at the construction site. At this time, all major Project excavations at the site are complete.

5. Risk of interference due to onsite migration of species of special status. Several species of special status have or could potentially inhabit undisturbed areas at the LLNL site. If this occurs, measures such as exclusion or buffer zones would be established in surrounding locations to minimize impacts from non-routine laboratory activities. At this time, most NIF activities are indoor and minimally or non-intrusive to the habitats of species of special status.

6. Risk of delay in DOE Critical Decision 3 (a 1 vel 0 milestone), approval of construction start is no longer a Prq est CD3 was a critical schedule constraint. Its delay would have entire project schedule and cost. This activity was comp te ISt iedule (DOE, 1997a).

7. Risk of the Title II design schedule not supporting the critical path construction schedule for conventional facilities and special equipment is no longer a Project risk. The Conventional es construction is complete. The Beampath Infrastructure Title Ut 1 -ómplete. The design of all special equipment is virtually oro . 1.1, ind there are no known significant problems that could impede design completion.

8. Risk of not getting technology results on schedule to support NIF design and procurement schedules, or to support meeting NIF performance requirements. Title II design is essentially complete and most technical challenges have been mitigated. First bundle operations will be used to verify most aspects of NIF performance. 
9. Risk that optics facilitization and pilot prod action will not provide adequate basis for NIF optics procurements facilitization and pilot prody inties were extremely successful and have provided the bas 5 procurements.

10. Risk of failure of the optics vendor base to produce the optics meeting NIF schedules, cost, and specifications is no longer a significant Project risk. NIF will require a large number of unique optics. Of the large optics, $75 \%$ are already in production, with $13 \%$ complete. Large optics delivery dates support the first bundle optics schedule. The optics that have been completed are, on average, significantly better than specification.

11. Risk of procured materials, construction or special equipment (non-optics) not being delivered or installed on time, or not meeting specifications. Some NIF materials and equipment may not be received on time, meet specifications upon delivery, or because of interferences discovered in the field, they may not be installed on time. Critical elements in reducing this risk are the identification of such items (Requirements Quality (RQ)-level assignment and associated strategy, e.g., inspections, functionality check, test, etc.), detailed planning, scheduling, and process control (e.g., procedures, etc.). In addition, a Production Organization has been established, Production Readiness Reviews are conducted, vendors are prescreened, and the vendor interface is actively maintained. Specialized modeling tools are used to aid the interference checks. The Area Integration Managers coordinate the priorities of System Engineering model checks with the line organizations in advance of installation. For areas where interfaces are most complex, such as steel structures interfacing to beampath and utilities in BIS, engineering design support specific to interference identification and resolution is emphasized within the engineering groups.

12. Risk of identifying installed out-of-specification components. Some NIF materials and equipment have unique characteristics or specifications. In order to minimize this risk and ensure that installed components meet specifications, an effective vendor quality assurance program and NIF receipt inspection program have been instituted.

13. Risk of Beampath Infrastructure System (BIS) critical path installation falling behind schedule due to labor difficulties, contractual problems, supplier problems, etc. Detailed planning and scheduling, use of multiple shifts, dispute resolution, Project Labor agreement, Owner Controlled Insurance Program, NIF Project Site Safety Program, have been implemented and proven beneficial to mitigate this risk.

14. Risk of inadequate requirements. Requirements define characteristics or functionality of NIF structures, systems, and components. Requirements derive from the Functional Requirements and Primary Criteria (LLNL, 1997c), and flow down through systems to subsystems. NIF requirements have been collected into the Requirements Management Database, and are reviewed on an ongoing basis for completeness. Engineering changes and non- 
conformances are reviewed using system models to assess performance impacts that could lead to the need for a new or revised requirement.

15. Risk of interference between any of BIS utility installations, special equipment installations, and initial operations. These are interleaved activities occurring in the same time frame in the same space. The Project engages in detailed planning and coordination to minimize cost and schedule impacts. This is addressed in the Integrated Project schedule and through daily coordination meetings. The NIF Project Site Safety Program (LLNL, 2001a) has been developed to address a mixed work environment and provides a uniform set of rules for site access, training, and work processes and controls.

16. Risk of change in regulatory requirements affecting design criteria during remaining design phases and construction/installation. The change of some regulatory requirements could affect design criteria. Although the design criteria were frozen in the Functional Requirements and Primary Criteria, the potential always exists for changes in regulatory requirements, which might require retrofit or re-design. The Project monitors the regulatory environment for impacts.

17. Risk of lost-time injuries occurring during construction, start-up and commissioning. Statistics indicate that worker injuries will occur during the NIF construction, start-up and commissioning period. This class of injury is not as severe as that identified in Item 18, to follow. Most of the injuries considered here (i.e., in element 17) will be relatively minor, but there may be significant injuries resulting in lost work time that may also occur. Such occurrences might have minor schedule impacts. During the next several years, a mixed work environment will exist, not all systems will be complete, and start-up and commissioning personnel will have limited experience working in the facility. The NIF Project Site Safety Program (NPSSP) (LLNL, 2001a) has been developed for the Project and this addresses the mixed work environment. It governs the safe conduct of all work at the NIF Project site. In addition, the Infrastructure Health and Safety Plan covers work under the IMI Contract. Numerous Project Control Procedures have been developed and issued to support the safe conduct of work at the NIF site. Failure Mode and Effect Analyses (FMEAs) are performed and included in Commissioning Test Plans to help identify failure modes so they can be addressed. Management Prestart Reviews are conducted prior to commencing activities introducing significant new risk. Site access safety training is thorough. Effective implementation of the safety program has dramatically improved the site safety record.

18. Risk of significant injury or fatal accident during NIF construction, start-up and commissioning. Severe injuries could impact the cost and schedule of the Project in a significant way while investigation and reviews are ongoing. Job Hazards Analyses, training and qualification, disciplinary action for safety violations all minimize risk and are incorporated into the NIF Project Site Safety Program. The NPSSP provides a uniform and rigorous set of safety requirements governing all activities at the site. A complete safety training 
program has also been implemented. Safety oversight and safety reviews contribute to reducing this risk.

19. Risk of regulation or permit violation during construction. This primarily includes DOE (OSHA) regulations, reporting requirements, or violating the requirements of the Storm Water Pollution Prevention Plan (SWPPP), wipecleaning permits or boiler permits. A significant program of self-assessment and audit for DOE (OSHA) compliance is ongoing.

20. Risk of severe natural phenomena occurring during construction. At this stage in the Project, the main risk from natural phenomena relates to a severe earthquake. This could result in damage to the facility, disrupt the site, or injuries. The design of NIF Structures, Systems, and Components has taken natural phenomena into account. The Institution has plans in place in the event of a severe earthquake.

21. Risk of delay in completing Management Prestart Reviews (MPRs) at points in the commissioning sequence in troducing significant new risk. The commissioning sequence has been broken into a series of logical Work Authorization Points (WAP). Prior to each WAP, a review of readiness to proceed occurs. MPRs are an audit of the ES\&H aspects of the WAP process for activities introducing significant new ES\&H risk, and are conducted by an independent, dedicated team. MPRs could result in findings that preclude the authorization for an activity until the finding is satisfactorily addressed.

Detailed planning has occurred to assure successful MPRs. Project personnel are aware of the requirements for MPRs and prepare required documentation in time for these reviews.

22. Risk of shortfalls in the NIF Demonstration Program resources to commission and start-up NIF. The NIF Demonstration Program will be providing facility management and start-up personnel that the Project is assuming will be available to support commissioning activities. Any delay or reduction in the annual demonstration funding will delay the Project completion date and affect the total estimated cost.

23. Risk of performance shortfall in the NIF laser systems that affect the ability to achieve performance requirements. Key performance requirements are identified by RQ-level assignment. For RQ-levels 1 and 2 items, quality strategies are developed and identify needed augmented specifications and/or work instructions to assure the requirement is met. In-depth review of designs at the midpoint and end of Title II design, combined with critical prototype evaluations, modeling, and analysis, are important design validation tools. In addition, the NIF Project uses an aggressive prototyping program, including the operation of Beamlet. The first bundle is an integrated test of all special equipment, and lessons learned will be applied to the procurement process. Engineering changes and non-conformances are reviewed using system models to assess performance impacts. FMEAs are performed to help identify failure modes, so that they can be addressed. 
24. Risk of a change in the regulatory agency. It is possible that the regulatory body overseeing LLNL facilities could change from DOE to another agency. This could result in new regulations or different interpretations of existing regulations. The Project is monitoring this issue.

25. Risk of cost growth. Cost growth, through commodity price increases/market factors (e.g., steel, concrete), labor rates increasing above the original plan, vendor quotes being higher than the government cost estimates, changes to existing contracts, or legal costs, could result. External factors, such as corporate closures or mergers, or other economic factors, could contribute as well. Legal costs could result from the preparation of a supplemental PEIS, legal defense, and the costs to perform site surveillances. The effort required in these areas is not fully known at this time, but the Project monitors contingency to mitigate against reasonable changes. Processes are in place to maintain tight controls on the Project cost and schedule.

26. Risk of delays in the Acquisition Executive approving Critical Decision 4. This marks completion of the project. Any delays would affect the total Project costs and defer Stockpile Stewardship testing.

27. Risk of data loss or compromise. The Project relies on numerous systems to develop, track, and store data. This includes financial and schedule information, as well as CAD, technical documents, procurement and manufacturing data, and test information. The Project and Institution use data archiving to mitigate against this possibility. 


\subsection{Risk Assessment and Management Measures}

The sections to follow describe the methodology that the Risk Assessment team developed to evaluate and rank the risks identified for the NIF Project. The results of the risk ranking are described, and risk mitigation measures are discussed.

\subsection{Risk Assessment Methodology}

Qualitative descriptors were assigned to risk element consequences and likelihoods. The risk element consequences and likelihoods were combined using a risk matrix to obtain an assessment of the relative risk presented by each risk element. The development of the risk matrix is the main subject of this section.

A $3 \times 3$ risk matrix is utilized to quantify each risk element, with consequences on the vertical axis and likelihood on the horizontal axis. To determine the relative risk presented by each of the nine blocks of the risk matrix, numerical values were assigned to the likelihood and consequence axes. The product of the numerical values of likelihood and consequence gives a numerical measure of risk for each block on the risk matrix. The numerical values on the risk matrix blocks are binned into risk ranges, allowing the relative risk of each of the nine blocks of the matrix to be known.

Each NIF risk element can be placed into a block on the matrix based on its associated likelihood and consequence. The relative risk category of the block where the risk element is placed provides the risk category for that risk element.

The basis for the numerical values for likelihoods and consequences used in establishing the risk matrix is given below. This is followed by the approach used for binning the blocks of the matrix into risk ranges. The risk matrix is provided at the end of this section.

\section{Likelihood Categories}

The likelihood of occurrence has been estimated in an order of magnitude fashion. The least likely category (A) includes risk elements that will probably not occur during the life of the project or that are extremely unlikely. This category has been assigned a numerical value of 1 . The most likely category $(C)$ would include risk elements that may be expected to occur during the life of the project. A numerical value of 100 was assigned to this category. The intermediate likelihood category (B) includes risk elements that are unlikely to occur during the life of the project. This category has a numerical value of 10 assigned to it. The likelihood categories are summarized below:

A: Probably will not occur/extremely unlikely during the Project (value =1) 
B: Unlikely that it will occur during the Project (value $=10$ )

C: Probably will occur during the Project (value $=100$ ).

\section{Consequence Categories}

Risk elements are broken down into four general types of impacts: performance, ES\&H, cost, and schedule. Guidelines used in placing risk elements into a consequence category are provided below for each of the four general types of impacts. These are also order of magnitude estimates, and each category is approximately an order of magnitude different in impact from the adjacent category(ies). To the extent feasible, an attempt is made to have the consequence levels represent approximately equivalent consequences for the four types of impacts. The consequence levels cover the range of potential impacts anticipated for NIF. As with the likelihoods, consequences are placed in three categories, identified as A, B, and C. Category A represents lower impacts, Category $B$ represents intermediate impacts, and Category $C$ represents higher impacts. The various categories for each type of impact are described below.

\section{Performance}

A: The facility can operate at full energy, but with slightly reduced beam quality (value $=1$ )

B: The facility provides operational capacity, but at reduced laser energy and power levels (value $=10$ )

C: The facility cannot operate at any useful level; laser energy and power are extremely limited (value $=100$ ).

\section{ES\&H}

A: Lost-time injuries to workers, minor impacts to public, minor environmental contamination (value $=1$ )

B: Significant disabling injuries to workers, single death of a worker, or major impacts to public, environmental impact requiring significant clean-up effort (value $=10)$

C: Multiple deaths of workers, equivalent impacts to public, substantial environmental impact with major environmental remediation needed (value = 100).

\section{Cost}

A: Less than $10 \mathrm{M} \$$ lost (value = 1)

$\underline{B}$ : Between 10 and $100 \mathrm{M} \$$ lost (value $=10$ )

C: More than $100 \mathrm{M} \$$ lost (value $=100$ ).

\section{Schedule}

A: Less than a few months (value $=1$ )

B: Few months to few years (value $=10$ )

C: Many years delay (value $=100)$. 


\section{Relative Risk Matrix and Relative Risk Levels}

The numerical values assigned to each consequence and likelihood category can be combined as a product to give risk values for each block of the risk matrix. The risk values corresponding to the likelihood and consequence scales established above are provided on Figure 1.

For the purpose of categorizing risks according to their relative importance, the blocks on the matrix were grouped into three relative risk levels. The highest level (Level III) corresponds to a combined risk measure greater than 1,000; the second category (Level II) corresponds to a risk measure greater than 100 up to and including 1,000; and the third and lowest risk category (Category I) corresponds to a risk measure of 100 or less.

\begin{tabular}{|c|c|c|r|}
\hline 100 & 1,000 & 10,000 & C (100) \\
\hline 10 & 100 & 1,000 & B (10) \\
\hline 1 & 10 & 100 & A (1) \\
\hline $\begin{array}{c}\text { A } \\
\text { (1) }\end{array}$ & $\begin{array}{c}\text { B } \\
(10)\end{array}$ & $\begin{array}{c}\text { C } \\
(100)\end{array}$ & $\begin{array}{r}\text { Consequence } \\
\text { Category }\end{array}$ \\
\hline \multicolumn{2}{|c|}{ Likelihood Category } \\
\cline { 1 - 3 }
\end{tabular}

\begin{tabular}{|l|l|}
\hline & $\begin{array}{l}\text { Level I Relative Risk } \\
(\leq 100)\end{array}$ \\
\hline $\begin{array}{l}\text { Level II Relative Risk } \\
(>100, \leq 1,000)\end{array}$ \\
$\begin{array}{l}\text { Level III Relative Risk } \\
(>1,000)\end{array}$ \\
\hline
\end{tabular}

Figure 1. Risk Matrix Utilized to Assess Relative Risk of NIF Risk Elements.

The blocks on the matrix were grouped into these risk levels based on the following. It would be reasonable to place a risk element that will probably occur during the life of the Project, and which would result in the lowest level of consequence (e.g., lost-time injuries, small schedule slip, or low-cost impact) in the lowest relative risk level. The numerical value on the block of the matrix associated with an element with a Category C likelihood (highest likelihood) and a Category A consequence (lowest consequence) is 100. Thus, the lowest relative risk level (Level I) would include all 
blocks on the matrix with numerical values up to and including 100 . Any element with a risk value less than or equal to the risk associated with a Category A consequence occurring during the Project lifetime (i.e., Category $\mathrm{C}$ likelihood) would fall into this risk range. The next highest level of relative risk, Level II, would include elements presenting 10 times greater risk than Level I risk elements. Level III relative risk would include elements presenting 10 times greater risk than the Level II category, and 100 times greater risk than the Level I risk category. These groupings are reflected on the matrix.

\subsection{Risk Assessment Results}

Table 1 provides a summary of the 27 identified risk elements and their consequences if they occurred (e.g., Critical Decision 4 being late will delay project completion by the same amount of time and involve a cost penalty averaging $\$ 5 \mathrm{M}$ per month). The table gives the assigned categories for likelihood of occurrence and the assigned categories for consequences for each type of consequence (i.e., performance, ES\&H, cost, and schedule). A bounding relative risk level is provided for each element. If a risk element could result in multiple types of consequences, then the risk level associated with each type of consequence was reviewed separately. The highest risk level associated with each risk element is listed in the table. The risk level assigned is representative of the cumulative risk associated with a given risk element over the life of the Project. Justification for assignment of likelihoods and consequences is provided in Appendix A. The original risk tables, generated in February of 1997 and April 1998, are included for comparison in Appendix B.

As shown in Table 1, the risk elements fall in Level I (lowest) and Level II (moderate) relative risk categories. There are no elements presenting a Level III relative risk. Risk elements determined to present a Level II risk are discussed in greater detail in the following paragraphs. This includes risk elements 11, 15, 18, and 27.

11. Risk of procured materials, construction or special equipment (non-optics) not being delivered or installed on time, or not meeting specifications. NIF materials and equipment may not be received on time, meet specifications upon delivery, or because of interferences discovered in the field, they may not be installed on time. Critical elements implemented by the Project to reduce thius risk are the identification of such items (RQ-level assignment and associated strategy, e.g., inspections, functionality check, test, etc.), detailed planning, scheduling, and process control (e.g., procedures, etc.). To minimize procurement risk, the NIF Project has established a Production Organization responsible for the strategy, planning, execution and oversight of significant contracts. Procurement Readiness reviews are conducted prior to contracting for significant items to assure the accuracy and completeness of documentation, the suitability of the candidate vendors, and to finalize plans for the oversight and management of the vendor. Upon award, contract kickoff meetings are conducted with the vendor to assure complete understanding of the requirements, $Q C$ provisions, and schedule. In the area of construction, a quality assurance program assures 
that the construction meets specifications. Also, the construction design packages are subject to a complete constructability review by the Integration Management and Installation (IMI) Contractor, Jacobs, to ensure that the sequence of installation is completely worked out, support equipment identified, crane use defined, and interfaces and interferences defined to ensure that the construction remains on schedule. Specialized modeling tools are used to aid the interference checks. The Area Integration Managers coordinate the priorities of System Engineering model checks with the line organizations in advance of installation. For areas where interfaces are most complex, such as steel structures interfacing to beampath and utilities in BIS, engineering design support specific to interference identification and resolution is emphasized within the engineering groups.

15. Risk of interference between any of BIS utility installation, special equipment installation, and initial operations. During one phase of the Project, BIS utility installation, special equipment installation, and initial operations will be ongoing simultaneously. These are interleaved activities occurring in the same time frame in the same space. Planning and coordination are essential to minimize cost and schedule impacts. Additional risk management measures include: having the Area Integration Managers as the single authority on priority and interference resolution within a specific geographic area, integrated schedule planning, contingency planning, daily coordination meetings, and separation of activities by area and shift.

18. Risk of significant injury or fatal accident during NIF construction, start-up and commissioning. This risk element presents a relatively higher ES\&H risk than other risk elements. There is also a cost and schedule risk associated with this element, but the ES\&H component dominates. In a project the size of NIF, statistics indicate that more than one death would be expected to occur during the activity. If a death were to occur, it is expected that all activity at the site would cease until the incident was fully investigated and the cause of the accident fully understood. The Project is performing better than the general construction industry. A Project Site Safety Program has been developed and has been distributed with the construction bid packages. The Jacobs Infrastructure Health and Safety Plan also applies to work under the IMI contract. To supplement this, there are the laboratory safety programs and DOE safety requirements. Numerous Project Control Procedures have been developed and issued to support the safe conduct of work at the NIF site. Failure Mode and Effect Analyses (FMEAs) are performed and included in Commissioning Test Plans to help identify failure modes so they can be addressed. Management Prestart Reviews are conducted prior to commencing activities introducing significant new risk. Workers are trained and qualified. The site access safety training addresses safety requirements and role-specific safety responsibilities. The ES\&H team is available for support, and there is a dedicated safety team at the site. With all of these mitigation measures, it is unlikely that a severe injury or death will occur during NIF construction. The NIF Integrated Safety Management Program has been reviewed by the DOE 
HQ Safety Management Evaluation Team and ES\&H subcommittees of NIF Project Status Reviews, and was identified as being a model of good management practice in this area.

27. Risk of cost growth. Cost growth could occur through commodity price increases / market factors (e.g., steel, concrete), labor rates increasing above the original plan, vendor quotes being higher than the government cost estimates, changes to existing contracts, or legal costs. External factors, such as corporate closures or mergers, or other economic factors, could contribute as well. Legal costs could result from the preparation of a supplemental PEIS, legal defense, and the costs to perform site surveillances. The effort required in these areas is not fully known at this time, but the Project actively monitors contingency to mitigate against reasonable changes. There are processes in place to maintain tight controls on the Project cost and schedule. The Project prudently allocates its contingency, and monitors markets in key areas that could affect costs (labor, commodities). The use of prequalified vendors gives greater confidence to the quality of vendor quotes. Maintaining close contact with vendors will minimize change orders and will assure that the products they are producing are what the Project requires (avoids costly rework). The Project periodically performs a self- assessment for cost reduction opportunities.

\subsection{Risk Management and Implementation}

Once risk elements are identified and reviewed, there are three potential courses of action:

1. Accept the risk without additional management measures,

2. Eliminate the risk to the maximum extent, and

3. Manage the risk to an acceptable level.

Once risks have been identified, a determination of acceptability is made. If the risk is not acceptable, means of eliminating or managing it are considered. If elimination is not possible, then ways of managing the risk are identified. Risk management measures are implemented until the level of risk becomes acceptable. Often, this point is determined by comparing probable costs if the risk element were to occur to the cost to manage the risk.

Risk management measures can function in two ways. They can:

- Reduce the likelihood of the risk element (preventive).

- Reduce the consequences of the risk element (mitigative).

Preventive measures are pro-active measures that assure the risk element does not occur. They work on the causes of why a certain risk element might occur and focus on making it less likely for a specific cause to actually take place. The second type of risk management measure attempts to alleviate the consequences of a risk element, if it 
occurs. This type focuses on ways of mitigating the consequence or provides an alternate pathway to follow if the risk element does occur (i.e., "Plan B"). Measures already implemented qualify as risk mitigation measures, if they have had an impact on reducing the likelihood of the risk element. Ongoing activities may also be included as risk management measures.

Preventive or mitigative measures have been developed for all of the identified risk elements. These are listed in Table 1. These measures range from detailed planning and scheduling of construction and equipment installation activities to the development of contingency plans (e.g., use of multi-shift, off-shift strategy, and overtime). A major risk management action is the clear definition and documentation of organization responsibility. This is done in the form of formal documents, such as the NIF Project Site Safety Program (LLNL, 2001a), which defines roles and responsibilities, such as the Area Integration Managers, who are a single authority for work going on in a specific area. That single authority establishes priorities, coordinates work within his/her area, and provides the method to resolve interferences and conflicts.

The NIF Project is very agile at addressing risks. An effective "working" risk management effort is in place. As specific risks are identified, actions are assigned and progress is tracked. Focus meetings are held for broad issues or those that require further study before they can be assigned. FMEAs are prepared as part of every Commissioning Test Plan to ensure proper attention is given to equipment failure modes. This very active risk identification process has resulted in attention being given to risks early on, so that they are addressed before they become more significant issues.

The identified risk mitigation measures are determined to be adequate, and have reduced the risk inherent in these NIF Project activities to acceptable levels. Through these actions, several of the previously identified higher risk items now present a lower risk to the Project. 


\subsection{References}

Brereton, S.J. (1993), Preliminary Hazards Analysis for the National Ignition Facility, UCRL-ID-116983, Lawrence Livermore National Laboratory, October 1993.

Brereton, S.J. (1997), FSAR Hazardous Event Table, NIF-0003412, September 1997.

DOE (2001a), National Ignition Facility Final Supplemental Environmental Impact

Statement to the Stockpile Stewardship and Management Programmatic

Environmental Impact Statement, DOE/EIS-0236-S1F, January 2001.

DOE (2001b), National Ignition Facility Project Execution Plan, U.S. Department of Energy, UCRL-ID-126525, Rev. 4, September, 2001.

DOE (1998), Supplement Analysis for the Use of Subgram Quantities of Uranium-238,

Depleted Uranium in NIF Non-yield Experiments, March 1998.

DOE (1997a), memo from V.H. Reis, through C.B. Curtis, "ACTION: Memorandum to the Energy Systems Acquisition Executive requesting approval of Critical Decision 3 (CD-3), Start of Construction for the National Ignition Facility (NIF)." , February 6, 1997, 1997-003291, approved by C.B. Curtis, March 7, 1997.

DOE (1997b), Mitigation Action Plan, National Ignition Facility, U.S. Department of Energy, Office of Defense Programs, Oakland Operations Office, February, 1997.

DOE (1996a), U.S. Department of Energy, "DOE Life Cycle Asset Management, Good Practice Guide, Risk Analysis and Management," GPG-FM-007, March 1996.

DOE (1996b), Final Programmatic Environmental Impact Statement for Stockpile Stewardship and Management, Volume III, Appendix I, National Ignition Facility Project Specific Analysis, DOE/EIS-0236, U.S. Department of Energy, September 1996.

DOE (1996c), Record of Decision: Programmatic Environmental Impact Statement for Stockpile Stewardship and Management, U.S. Department of Energy, [6450-01-P], December 19, 1996.

Jacobs, (2000), Infrastructure Health and Safety Plan, Project Procedure IMI-1.1, Jacobs Facilities, Inc., October 2000.

Jensen, J. (1997), National Ignition Facility Laser and Target Area Building (LTAB) Fire Hazards Analysis, Draft, February 1997.

LLNL, (2002a), National Ignition Facility Quality Assurance Program Plan, Rev. 1, Lawrence Livermore National Laboratory, NIF-0054117, February 2002.

LLNL (2002b), National Ignition Facility Programs Training Plan, Rev. 1, Lawrence Livermore National Laboratory, NIF-0054619, January 2002.

LLNL, (2002c) NIF Project Procedure 1.3, Schedule Preparation, Statusing, and Revision, Rev. 5, NIF-0000320, Lawrence Livermore National Laboratory, May 2002. 
LLNL, (2002d), NIF Project Procedure 1.12, Project Performance Measurement Using Earned Value, Rev. 1, NIF-0072079, Lawrence Livermore National Laboratory, May 2002.

LLNL, (2002e), NIF Project Procedure 9.3, Safety and Performance Review Board, Management Prestart Reviews, and Work Group Reviews, Rev. 3, NIF-0023636, Lawrence Livermore National Laboratory, April 2002.

LLNL, (2001a), NIF Project Site Safety Program, Rev. 4, UCRL-ID-125990, Lawrence Livermore National Laboratory, September 2001.

LLNL, (2001b), NIF Project Procedure 1.2, Cost Estimating, Rev. 6, NIF-0001205, Lawrence Livermore National Laboratory, November 2001.

LLNL, (2001c), NIF Project Procedure 7.4, Procurement Planning, scheduling, Review, and Approval, Rev. 4, NIF-0003695, Lawrence Livermore National Laboratory, October 2001.

LLNL, (2001d), NIF Project Procedure 8.1, Suspect/Counterfeit Items Detection and Prevention, Rev. 2, NIF-0001458, Lawrence Livermore National Laboratory, October 2001.

LLNL, (2000a), NIF Project Procedure 5.1, Engineering Design Reviews, Rev. 6, NIF0003039 , July 2000.

LLNL, (2000b), NIF Project Procedure 7.1, Supplier Qualification, Rev. 2, NIF-0001014, Lawrence Livermore National Laboratory, July 2000.

LLNL, (2000c), NIF Project Procedure 7.3, Vendor Surveillance, Rev. 1, NIF-0050985, Lawrence Livermore National Laboratory, July 2000.

LLNL (1999), National Ignition Facility Final Safety Analysis Report, Preliminary Draft, Lawrence Livermore National Laboratory, UCRL-ID-139329, March 1999.

LLNL (1998), National Ignition Facility Risk Management Plan, Rev. 1, Lawrence Livermore National Laboratory, UCRL-ID-126809, NIF-0001564-OB, April 1998.

LLNL (1997a), National Ignition Facility Risk Management Plan, Lawrence Livermore National Laboratory, UCRL-ID-126809, NIF-0001564-OA, February 1997.

LLNL (1997b), National Ignition Facility Reliability, Availability, and Maintainability Plan, NIF-0003141, October, 1997.

LLNL (1997c), National Ignition Facility Functional Requirements and Primary Criteria, Rev. 1.6, NIF0001006-OC, Lawrence Livermore National Laboratory, March 1997.

LLNL (1997d), Construction Safety Program for the National Ignition Facility, UCRLID-125990 Rev 1, Lawrence Livermore National Laboratory, June 1997.

LLNL (1997e), NIF Special Equipment Construction Health and Safety Plan, UCRL-ID127610, Lawrence Livermore National Laboratory, July 1997.

LLNL (1997f), National Ignition Facility Project Execution Plan, Appendix C, Project Data Sheet, UCRL-ID-126525, Rev. 1, August 1997. 
LLNL (1997g), National Ignition Facility Project Control Procedure, No. 1.6, "Assignment of Quality Levels," NIF-0004018, December 1997.

LLNL (1997h), National Ignition Facility Site Management Plan, UCRL-ID-127904, September 1997.

LLNL (1996a), National Ignition Facility Preliminary Safety Analysis Report, UCRL-ID123759, Lawrence Livermore National Laboratory, September 1996.

LLNL (1996b), National Ignition Facility Quality Assurance Program Plan, Rev. 1, NIF0000618, September 1996.

LLNL (1994), NIF Conceptual Design Report Appendix A Vol1, Bk 1, UCRL-PROP117093, May 1994.

Singh, M. (1993), Radiological Analysis of the National Ignition Facility, Lawrence Livermore National Laboratory, UCRL-LR-115188, October 1993. 
Table 1. Likelihood, consequences, and relative risk of NIF Risk Elements and associated mitigation measures (updated 6/13/02).

\begin{tabular}{|c|c|c|c|c|c|c|c|c|c|}
\hline \multirow[b]{2}{*}{ Likelihood } & \multicolumn{4}{|c|}{ Consequences } & \multirow{2}{*}{$\begin{array}{c}\text { Bounding } \\
\text { Relative } \\
\text { Risk }\end{array}$} & \multirow[b]{2}{*}{ Identified risk element } & \multirow[b]{2}{*}{$\begin{array}{l}\text { Near } \\
\text { Term }\end{array}$} & \multirow{2}{*}{\multicolumn{2}{|c|}{ Planned mitigation measures }} \\
\hline & Perf & ES\&H & Cost & Schedule & & & & & \\
\hline B & & & B & B & $\mathrm{I}$ & $\begin{array}{l}\text { 1. Risk of not getting requested Congressional } \\
\text { authorization and appropriation (note: litigants are actively } \\
\text { lobbying Congress). }\end{array}$ & Yes & $\begin{array}{l}\text { - Maintain high priority of NIF with Stockpile } \\
\text { Stewardship decision-makers } \\
\text { - Presentations of NIF progress and priority to } \\
\text { Congressional hearings } \\
\text { - Demonstrate environmental concern and due } \\
\text { diligence in all construction work (e.g., } \\
\text { quarterly report, public information release) }\end{array}$ & $\begin{array}{l}\text { - Properly handle all audits (GAO, NAE, etc.) } \\
\text { - Propose full funding each year. }\end{array}$ \\
\hline N/A & N/A & $\mathrm{N} / \mathrm{A}$ & N/A & N/A & $\mathrm{N} / \mathrm{A}$ & $\begin{array}{l}\text { 2. Risk of delay in obtaining environmental permits that } \\
\text { constrain the start of construction. }\end{array}$ & & Completed. & \\
\hline N/A & N/A & N/A & N/A & N/A & N/A & $\begin{array}{l}\text { 3. Risk of a successful legal challenge of the PEIS on } \\
\text { Stockpile Stewardship Program. }\end{array}$ & & Completed. & \\
\hline $\mathrm{N} / \mathrm{A}$ & N/A & $\mathrm{N} / \mathrm{A}$ & N/A & $\mathrm{N} / \mathrm{A}$ & N/A & $\begin{array}{l}\text { 4. Risk of finding paleontological (e.g., fossils) or } \\
\text { archeological artifacts. }\end{array}$ & & Completed. & \\
\hline A & & & A & A & I & $\begin{array}{l}\text { 5. Risk of interference due to onsite migration of species of } \\
\text { special status. }\end{array}$ & Yes & $\begin{array}{l}\text { - Establish construction activity baselines for } \\
\text { nesting period of White-tailed Kites } \\
\text { - Obtain "Biological Opinion" by U.S. Fish and } \\
\text { Wildlife Services for the Red-legged Frog, } \\
\text { which identifies practicable mitigation } \\
\text { measures for encounters at NIF locations }\end{array}$ & - Most activities now indoors \\
\hline $\mathrm{N} / \mathrm{A}$ & $\mathrm{N} / \mathrm{A}$ & N/A & N/A & N/A & N/A & $\begin{array}{l}\text { 6. Risk of delay in DOE Critical Decision 3, approval of } \\
\text { construction start. }\end{array}$ & & Completed. & \\
\hline N/A & $\mathrm{N} / \mathrm{A}$ & N/A & N/A & $\mathrm{N} / \mathrm{A}$ & N/A & $\begin{array}{l}\text { 7. Risk of Title II design schedule not supporting the } \\
\text { critical path construction schedule for conventional } \\
\text { facilities and special equipment. }\end{array}$ & & Completed. & \\
\hline B & B & & B & B & I & $\begin{array}{l}\text { 8. Risk of not getting technology results on schedule to } \\
\text { support NIF design and procurement schedules, or to } \\
\text { support meeting NIF performance requirements. }\end{array}$ & Yes & $\begin{array}{l}\text { - Work with vendors to assure quality } \\
\text { Ensure support for technology development } \\
\text { and testing }\end{array}$ & - Test on NIF first bundle \\
\hline $\mathrm{N} / \mathrm{A}$ & N/A & N/A & $\mathrm{N} / \mathrm{A}$ & N/A & N/A & $\begin{array}{l}\text { 9. Risk that optics facilitization and pilot production will } \\
\text { not provide adequate basis for NIF optics procurements. }\end{array}$ & & Completed. & \\
\hline A & B & & B & B & I & $\begin{array}{l}\text { 10. Risk of failure of the optics vendor base to produce the } \\
\text { optics meeting NIF schedules, cost, and specifications. }\end{array}$ & & $\begin{array}{l}\text { - Multiple vendors } \\
\text { - Production contingency for key optics } \\
\text { Early optics production }\end{array}$ & $\begin{array}{l}\text { - Qualified vendor base } \\
\text { - Coordinate procurements with AWE/CEA } \\
\text { to limit conflict and enhance the vendor base }\end{array}$ \\
\hline
\end{tabular}


Table 1. Continued.

\begin{tabular}{|c|c|c|c|c|c|c|c|c|c|}
\hline \multirow[b]{2}{*}{ Likelihood } & \multicolumn{4}{|c|}{ Consequences } & \multirow{2}{*}{$\begin{array}{c}\text { Bounding } \\
\text { Relative } \\
\text { Risk } \\
\end{array}$} & \multirow[b]{2}{*}{ Identified risk element } & \multirow[b]{2}{*}{$\begin{array}{l}\text { Near } \\
\text { Term }\end{array}$} & \multirow{2}{*}{\multicolumn{2}{|c|}{ Planned mitigation measures }} \\
\hline & Perf & ES\&H & Cost & Schedule & & & & & \\
\hline C & A & B & B & B & II & $\begin{array}{l}\text { 11. Risk of procured materials, construction, or special } \\
\text { equipment (nonoptics) not being delivered or installed on } \\
\text { time, or not meeting specifications. }\end{array}$ & Yes & $\begin{array}{l}\text { - Procurement Procedure (Project Procedure 7.4) } \\
\text { - Detailed procurement plan } \\
\text { - Vendor surveys } \\
\text { - Prequalified bidders } \\
\text { Revelop/implement Quality Strategies for } \\
\text { RQ-1 and RQ-2 requirements }\end{array}$ & $\begin{array}{l}\text { - Focus on vendor interface } \\
\text { - Vendor QA Plan } \\
\text { - Production organization } \\
\text { - Procurement readiness reviews } \\
\text { - Contract kick-off meetings } \\
\text { - Active QA/QC } \\
\text { - Constructability reviews } \\
\end{array}$ \\
\hline $\mathrm{C}$ & & A & A & A & I & $\begin{array}{l}\text { 12. Risk of identifying installed out-of-specification } \\
\text { components. }\end{array}$ & Yes & $\begin{array}{l}\text { - Procurement Procedure (Project Procedure 7.4) } \\
\text { - Detailed procurement plan } \\
\text { - Pendor surveys } \\
\text { Prequalified bidders } \\
\text { Develop/implement Quality Strategies for } \\
\text { RQ-1 and RQ-2 items requirements }\end{array}$ & $\begin{array}{l}\text { - Robust receipt inspection program } \\
\text { - Vendor QA Plan } \\
\end{array}$ \\
\hline B & & & B & A & I & $\begin{array}{l}\text { 13. Risk of BIS critical path installation falling behind } \\
\text { schedule due to labor difficulties, contractual problems, } \\
\text { supplier problems, etc. }\end{array}$ & Yes & $\begin{array}{l}\text { - Detailed schedule and plans } \\
\text { - CM coordination and tracking } \\
\text { - Incentives to contractors }\end{array}$ & $\begin{array}{l}\text { - Project labor agreement } \\
\text { - Alternate dispute resolution process } \\
\text { Owner-controlled insurance policy }\end{array}$ \\
\hline B & A & & B & B & I & 14. Risk of inadequate requirements. & Yes & $\begin{array}{l}\text { - Requirements management system } \\
\text { - RQ levels and strategy }\end{array}$ & $\begin{array}{l}\text { - Performance modeling } \\
\text { - Engineering design support specific to } \\
\text { interference identification and resolution }\end{array}$ \\
\hline C & & & B & B & II & $\begin{array}{l}\text { 15. Risk of interference between any of BIS utilities } \\
\text { installation, special equipment installation, and initial } \\
\text { operations. }\end{array}$ & Yes & $\begin{array}{l}\text { - Integrated schedule planning } \\
\text { - Contingency planning } \\
\text { - Saily coordination meetings } \\
\text { oparate activities by area and shift - } \\
\text { shift }\end{array}$ & $\begin{array}{l}\text { - QA Plan } \\
\text { Risk reduction planning (e.g., use of off-shift) } \\
\text { - Incentives to contractors } \\
\text { - NPSSP applies to mixed work environment }\end{array}$ \\
\hline A & B & & B & B & I & $\begin{array}{l}\text { 16. Risk of change in regulatory requirements affecting } \\
\text { design criteria during remaining design phases and } \\
\text { construction/installation. }\end{array}$ & Yes & $\begin{array}{l}\text { - Maintain awareness of regulation changes } \\
\text { - Minimize use of hazardous materials, utilize } \\
\text { relatively benign materials }\end{array}$ & $\begin{array}{l}\text { - Approved Function Requirements/Primary } \\
\text { Criteria }\end{array}$ \\
\hline c & & A & A & A & I & $\begin{array}{l}\text { 17. Risk of lost-time injuries occurring during } \\
\text { construction, start-up and commissioning. }\end{array}$ & Yes & $\begin{array}{l}\text { - NIF Project Site Safety Program (NPSSP) } \\
\text { - Jacobs Infrastructure Health \& Safety Plan } \\
\text { - Training and qualification } \\
\text { - Zero injury techniques } \\
\text { - DOE safety requirements } \\
\text { - NPSSP updated to add lessons learned } \\
\text { - Monthly and quarterly safety audits } \\
\text { - Laboratory safety programs } \\
\text { - ES\&H team } \\
\end{array}$ & $\begin{array}{l}\text { - NIF Project Safety Team (root cause analysis, } \\
\text { lessons learned) } \\
\text { - Safety officers, inspectors } \\
\text { - Job hazards analysis } \\
\text { Site safety oversight increased based on } \\
\text { lessons learned } \\
\text { - Disciplinary action for safety violations } \\
\text { - Project Procedures for safe conduct of work }\end{array}$ \\
\hline B & & C & B & B & II & $\begin{array}{l}\text { 18. Risk of significant injury or fatal accident during NIF } \\
\text { construction, start-up and commissioning. }\end{array}$ & Yes & $\begin{array}{l}\text { - NIF Project Site Safety Program } \\
\text { - Jacobs Infrastructure Health \& Safety Plan }\end{array}$ & $\begin{array}{l}\text { - NIF Project Safety Team (root cause analysis, } \\
\text { lessonslearned) }\end{array}$ \\
\hline & & & & & & & & $\begin{array}{l}\text { - Training and qualification } \\
\text { - Zero injury techniques } \\
\text { - DOE safety requirements } \\
\text { - NPSSP updated to add lessons learned } \\
\text { - Lonthly and quarterly safety audits } \\
\text { - ES\&H team }\end{array}$ & $\begin{array}{l}\text { - Safety officers, inspectors } \\
\text { - Job hazards analysis } \\
\text { lessonstety oversight increased based on } \\
\text { - Disciplinary action for safety violations } \\
\text { - Project Procedures for safe conduct of work }\end{array}$ \\
\hline
\end{tabular}


Table 1. Continued.

\begin{tabular}{|c|c|c|c|c|c|c|c|c|c|}
\hline \multirow{3}{*}{$\frac{\text { Likelihood }}{\text { B }}$} & \multicolumn{4}{|c|}{ Consequences } & \multirow{3}{*}{\begin{tabular}{c|}
$\begin{array}{c}\text { Bounding } \\
\text { Relative } \\
\text { Risk }\end{array}$ \\
I
\end{tabular}} & \multirow{3}{*}{\begin{tabular}{|l|}
\multicolumn{1}{|c}{ Identified risk element } \\
$\begin{array}{l}\text { 19. Risk of regulation or permit violation during } \\
\text { construction. }\end{array}$
\end{tabular}} & \multirow{3}{*}{$\begin{array}{l}\text { Near } \\
\text { Term }\end{array}$} & \multirow{2}{*}{\multicolumn{2}{|c|}{ Planned mitigation measures }} \\
\hline & \multirow[t]{2}{*}{ Perf } & \multirow{2}{*}{$\frac{\text { ES\&H }}{B}$} & \multirow{2}{*}{$\frac{\text { Cost }}{A}$} & \multirow{2}{*}{$\frac{\text { Schedule }}{\mathrm{A}}$} & & & & & \\
\hline & & & & & & & & $\begin{array}{l}\text { - Construction Safety Program } \\
\text { - Conventional Facilities and Special } \\
\text { Equipment Construction Safety Plans } \\
\text { - Zero injury techniques } \\
\text { - ES\&H team }\end{array}$ & $\begin{array}{l}\text { - Construction safety officers, construction } \\
\text { inspectors } \\
\text { - Designated responsible individual for } \\
\text { implementing SWPPP } \\
\text { - Subcontractor SWPPP training of responsible } \\
\text { individual }\end{array}$ \\
\hline B & & B & B & A & I & $\begin{array}{l}\text { 20. Risk of severe natural phenomena occurring during } \\
\text { construction. }\end{array}$ & Yes & $\begin{array}{l}\text { - Biological opinion and arroyo clearing to } \\
\text { reduce flood hazard (El Niño) } \\
\text { - Planning for El Niño (e.g., diking, use of soil } \\
\text { treatments to minimize water penetration) } \\
\text { - Emergency Plan } \\
\text { - Training }\end{array}$ & $\begin{array}{l}\text { - NIF OPR Change Control Board (ICF/NIF } \\
\text { Programs) to control cost/schedule } \\
\text { - Prepare detailed start-up plans } \\
\text { - Obtain AWE funds for technology } \\
\text { transfer/AWE staff for start-up in } \\
\text { preparation for Helen Replacement laser } \\
\text { - Perform formal acceptance test procedures } \\
\end{array}$ \\
\hline B & & & A & A & I & $\begin{array}{l}\text { 21. Risk of delay in completing Management Prestart } \\
\text { Reviews at points in the commissioning sequence } \\
\text { introducing significant new risk. }\end{array}$ & Yes & $\begin{array}{l}\text { MPR plan prepared early on } \\
\text { - WAP process }\end{array}$ & $\begin{array}{l}\text { - MPRs are Level } 3 \text { milestones } \\
\text { - Dedicated, standing MPR committee }\end{array}$ \\
\hline B & & & B & в & I & $\begin{array}{l}\text { 22. Risk of shortfalls in the NIF Demonstration Program } \\
\text { resources to commission and start-up NIF. }\end{array}$ & Yes & $\begin{array}{l}\text { - High priority of Stockpile Stewardship } \\
\text { Program in DP/commitment of LLNL } \\
\text { Laboratory Director } \\
\text { - High priority of NIF operation } \\
\text { - Phasing of Nova shutdown and NIF } \\
\text { activation } \\
\text { - Level of funding may be reduced but balance } \\
\text { would be maintained to support the ICF } \\
\text { program }\end{array}$ & \\
\hline $\mathrm{A} / \mathrm{B}$ & $\mathrm{C} / \mathrm{A}$ & & $\mathrm{C} / \mathrm{A}$ & $\mathrm{C} / \mathrm{A}$ & I & $\begin{array}{l}\text { 23. Risk of performance shortfall in the NIF special } \\
\text { equipment systems that affect the ability to achieve } \\
\text { performance requirements. }\end{array}$ & No & $\begin{array}{l}\text { - Off-line laboratory (e.g., AMPLAB) results } \\
\text { Beamlet results } \\
\text { QA Plan including quality levels } \\
\text { - Aggressive prototyping program } \\
\text { that identiffy areas for augmented } \\
\text { specification or work interactions for critical } \\
\text { items (RQ levels) }\end{array}$ & $\begin{array}{l}\text { - Technology development/prototyping results } \\
\text { - NEL } \\
\text { - Formal design reviews } \\
\text { - Perform formal acceptance test procedures } \\
\text { - Review of perforemance impacts of changes \& } \\
\text { nonconformances } \\
\text { - FMEAs }\end{array}$ \\
\hline B & & & A & A & I & $\begin{array}{l}\text { 24. Risk of a change in the regulatory agency (DOE to } \\
\text { NRC or other). }\end{array}$ & & No longer a Project risk. & \\
\hline c & & & B & & II & 25. Risk of cost growth. & Yes & $\begin{array}{l}\text { - Contingency available } \\
\text { - Prequalification of vendors } \\
\text { - Minimize change orders }\end{array}$ & $\begin{array}{l}\text { - Plan of action, describing proposed actions to } \\
\text { eliminate or ameliorate cost growth } \\
\text { - Maintain close contact with vendors }\end{array}$ \\
\hline & & & & & & & & $\begin{array}{l}\text { - Uíonitor markeis } \\
\text { - Update of cost estimates } \\
\text { - Change control process }\end{array}$ & $\begin{array}{l}\text {-ptionstor purchasingergon quantity vistime, } \\
\text { - Cost reduction efforts focusing on designing } \\
\text { to cost and limiting cost growth }\end{array}$ \\
\hline A & & & B & B & I & $\begin{array}{l}\text { 26. Risk of delays in the Acquisition Executive approving } \\
\text { CD } 4 .\end{array}$ & No & $\begin{array}{l}\text { Majority of project already turned over by } \\
\text { CD4 } \\
\text { Experience basis of several years of operation } \\
\text { prior to CD4 }\end{array}$ & - Conservative design \\
\hline
\end{tabular}




$$
\text { CTITTI W }
$$




\section{APPENDIX A}

\section{Justification of Consequences and Likelihoods used in Relative Risk Assessment}

Likelihood categories utilized in assessing Project risk elements are summarized below:

A: Probably will not occur/extremely unlikely during the Project (value $=1$ )

B: Unlikely that it will occur during the Project (value $=10$ )

C: Probably will occur during the Project (value $=100$ ).

Consequence Categories utilized in assessing Project risk elements are summarized below:

\begin{tabular}{|l|l|l|l|}
\hline \multicolumn{1}{|c|}{ Type } & \multicolumn{1}{|c|}{$\begin{array}{c}\text { Category A: } \\
\text { Value=1 }\end{array}$} & \multicolumn{1}{c|}{$\begin{array}{c}\text { Category B: } \\
\text { Value=10 }\end{array}$} & \multicolumn{1}{c|}{$\begin{array}{c}\text { Category C: } \\
\text { Value=100 }\end{array}$} \\
\hline$\underline{\text { Performance }}$ & $\begin{array}{l}\text { Facility can operate } \\
\text { at full energy, but } \\
\text { with slightly reduced } \\
\text { beam quality }\end{array}$ & $\begin{array}{l}\text { Facility provides } \\
\text { some operational } \\
\text { capacity, but at } \\
\text { reduced laser energy } \\
\text { and power levels }\end{array}$ & $\begin{array}{l}\text { Facility can't operate } \\
\text { at any useful level; } \\
\text { laser energy and } \\
\text { power are extremely } \\
\text { limited }\end{array}$ \\
\hline$\underline{\text { ESEH }}$ & $\begin{array}{l}\text { Lost-time injuries to } \\
\text { workers; minor } \\
\text { impacts to the public; } \\
\text { contamination }\end{array}$ & $\begin{array}{l}\text { Significant disabling } \\
\text { worker injuries; } \\
\text { single death of a } \\
\text { worker; major } \\
\text { impacts to public; or } \\
\text { environmental } \\
\text { impact requiring } \\
\text { significant clean-up } \\
\text { effort }\end{array}$ & $\begin{array}{l}\text { Multiple worker } \\
\text { deaths; equivalent } \\
\text { impacts to the public; } \\
\text { substantial } \\
\text { environmental } \\
\text { impact with major } \\
\text { environmental } \\
\text { remediation needed }\end{array}$ \\
\hline$\underline{\text { Cost }}$ & Less than 10 M\$ lost & $\begin{array}{l}\text { Between 10 and 100 } \\
\text { M\$ lost }\end{array}$ & $\begin{array}{l}\text { More than 100 M\$ } \\
\text { lost }\end{array}$ \\
\hline$\underline{\text { Schedule }}$ & $\begin{array}{l}\text { Less than a few } \\
\text { months delay }\end{array}$ & $\begin{array}{l}\text { Few months to few } \\
\text { years delay }\end{array}$ & Many years delay \\
\hline
\end{tabular}

Risk levels are determined by assigning a likelihood and consequence level to each risk element, then placing the risk element on the risk matrix in Figure 1. The risk level of the block where the risk element is placed represents the relative risk associated with that element. 
1. Risk of not getting the requested Congressional authorization and appropriation.

Cost Consequence:

Schedule Consequence:

Likelihood:

Cost Relative Risk:

Schedule Relative Risk:

Bounding Relative Risk:
B $10-100 \$ M$

B Could result in a few months to a few years slippage, if all requested funding is not received

B High priority item within Stockpile Stewardship

I

I

I

2. Risk of delay in obtaining environmental permits that constrain the start of construction (complete).

Cost Consequence:

N/A

Schedule Consequence:

$\mathrm{N} / \mathrm{A}$

Likelihood:

$\mathrm{N} / \mathrm{A}$

Cost Relative Risk:

$\mathrm{N} / \mathrm{A}$

Schedule Relative Risk:

$\mathrm{N} / \mathrm{A}$

Bounding Relative Risk:

N/A

3. Risk of a successful legal challenge of the PEIS on Stockpile Stewardship and Management (complete).

Cost Consequence: $\mathrm{N} / \mathrm{A}$

Schedule Consequence:

$\mathrm{N} / \mathrm{A}$

Likelihood:

$\mathrm{N} / \mathrm{A}$

Cost Relative Risk:

$\mathrm{N} / \mathrm{A}$

Schedule Relative Risk:

N/A

Bounding Relative Risk:

N/A

4. Risk of finding paleontological finds (e.g., animal fossils) or cultural resources (e.g., archeological artifacts) (complete).

Cost Consequence:

N/A

Schedule Consequence:

N/A

Likelihood:

$\mathrm{N} / \mathrm{A}$

Cost Relative Risk:

N/A 
$\begin{array}{ll}\text { Schedule Relative Risk: } & \text { N/A } \\ \text { Bounding Relative Risk: } & \text { N/A }\end{array}$

5. Risk of interference due to onsite migration of species of special status.

Cost Consequence:

Schedule Consequence:

Likelihood:

Cost Relative Risk:

Schedule Relative Risk:

Bounding Relative Risk:
A $\quad<5-10 \mathrm{M} \$$ due to schedule slippage

A Could result in delay of certain activities that are prohibited within the buffer zone

A Active planning, most activities are now indoors.

6. Risk of delay in DOE Critical Decision 3, approval of construction start. (complete).

Cost Consequence: N/A

Schedule Consequence:

N/A

Likelihood:

$\mathrm{N} / \mathrm{A}$

Cost Relative Risk:

$\mathrm{N} / \mathrm{A}$

Schedule Relative Risk:

$\mathrm{N} / \mathrm{A}$

Bounding Relative Risk:

$\mathrm{N} / \mathrm{A}$

7. Risk of the Title II design schedule not supporting the critical path construction schedule for conventional facilities and special equipment (complete).

Cost Consequence:

N/A

Schedule Consequence:

$\mathrm{N} / \mathrm{A}$

Likelihood:

$\mathrm{N} / \mathrm{A}$

Cost Relative Risk:

$\mathrm{N} / \mathrm{A}$

Schedule Relative Risk:

$\mathrm{N} / \mathrm{A}$

Bounding Relative Risk:

$\mathrm{N} / \mathrm{A}$

8. Risk of not getting technology results on schedule to support NIF design and procurement, or to support meeting NIF performance requirements.

Performance Consequence:

B Facility may only be able to operate at reduced energy and power levels (and then would not incur schedule consequence) 
Cost Consequence:

Schedule Consequence:

Likelihood:

Performance Relative Risk:

Cost Relative Risk:

Schedule Relative Risk:

Bounding Relative Risk:
B $\quad 10-100 \$ M$ due to replacement costs and schedule delays for replacement activities

B Delay of many months to a year, if high failure rate during commissioning; reduced availability during operations

B New technology

I

I

9. Risk that optics facilitization and pilot production will not provide adequate basis for NIF optics procurements (complete).

Performance Consequence: N/A

Cost Consequence: N/A

Schedule Consequence: $\quad$ N/A

Likelihood: N/A

Performance Relative Risk: $\quad$ N/A

Cost Relative Risk: N/A

Schedule Relative Risk: N/A

Bounding Relative Risk: N/A

10. Risk of failure of the optics vendor base to produce the optics meeting NIF schedules, costs, and specifications (complete).

Performance Consequence:

B Facility will be partially operable with limited optics available

Cost Consequence:

B > $10 \mathrm{M} \$$ due to schedule delays

Schedule Consequence:

B Possibly many months to a year or so

Likelihood:

A Extremely unlikely at this stage in the Project

Performance Relative Risk: I

Cost Relative Risk: I

Schedule Relative Risk: I

Bounding Relative Risk: I

11. Risk of procured materials, construction or special equipment (non-optics) not being delivered or installed on time, or not meeting specifications.

Performance Consequence:

A Facility performance may be limited 
ES\&H Consequence:

Cost Consequence:

Schedule Consequence:

Likelihood:

Performance Relative Risk: II

ES\&H Relative Risk: II

Cost Relative Risk: II

Schedule Relative Risk: II

Bounding Relative Risk: II
B Component not meeting specification could lead to injury

B >10\$M due to schedule slippage, plus cost to upgrade or redesign

B Possibly few months delay to upgrade, replace, etc.

C Many unique aspects of NIF equipment

\section{(1)}

(I)

II
II

12. Risk of identifying installed out-of-specification components.

Performance Consequence:

Cost Consequence:

Schedule Consequence:

Likelihood:

Performance Relative Risk:

Cost Relative Risk:

Schedule Relative Risk:

Bounding Relative Risk:
A Minor effect

A Possibly few months delay to upgrade, replace, etc.; most likely would be small item (e.g., fasteners)

A Less than a few months to remove, replace, etc.

C

I

I

13. Risk of BIS critical path installation falling behind schedule due to labor difficulties, contractual problems, supplier problems, etc.

Cost Consequence:

Schedule Consequence:

Likelihood:

Cost Relative Risk:

Schedule Relative Risk:

Bounding Relative Risk:
B > 10\$M due to schedule, possibly additional labor/supply costs

A Up to a few months delay possible

B Labor situation appears stable, BIS management planning 
14. Risk of inadequate requirements.

Performance Consequence:

Cost Consequence:

Schedule Consequence:

Likelihood:

Performance Relative Risk:

Cost Relative Risk:

Schedule Relative Risk:

Bounding Relative Risk:
A Facility performance may be limited

B > $10 \$ M$ due to schedule slippage, plus cost to upgrade or redesign

B Possibly few months delay to upgrade, replace, etc.

B Many unique and complicated aspects of NIF equipment (could also have more likely scenarios, but impacts will be less; risk is the same)

15. Risk of interference between any of BIS utilities installations, special equipment installations, and initial operations.

Cost Consequence:

Schedule Consequence:

Likelihood:

Cost Relative Risk:

Schedule Relative Risk:

Bounding Relative Risk:
B $>10 \$ M$ due to schedule delays

B Could result in many months of delays (construct/install in series, rather than parallel)

C Schedule planning to minimize conflict, however, because of the number of simultaneous activities, some conflicts are expected to arise

II

II

II (Cost and schedule risks are bounding)

16. Risk of change in regulatory requirements affecting design criteria during remaining design phases and construction/installation.

Performance Consequence:

Cost Consequence:
B May be unable to perform certain activities in the desired fashion to obtain performance (e.g., recoat optics using certain material)

B > 10\$M for re-work, re-development or retrofit 
Schedule Consequence:

Likelihood:

Performance Relative Risk:

Cost Relative Risk:

Schedule Relative Risk:

Bounding Relative Risk:
B Delays could resuit if re-work, redevelopment or retrofit required

A

I

I

I

I

17. Risk of lost-time injuries occurring during construction, start-up and commissioning.

ES\&H Consequence:

Cost Consequence:

Schedule Consequence:

Likelihood:

Cost Relative Risk:

Schedule Relative Risk:

Bounding Relative Risk
A Lost-time injuries

A Minor cost impacts

A Minor schedule impact, if investigation needed

C Expected during a construction project of this size

I

I

I

18. Risk of significant injury or fatal accident during NIF construction, start-up and commissioning.

ES\&H Consequence:

Cost Consequence:

Schedule Consequence:

Likelihood:

ES\&H Relative Risk:

Cost Relative Risk:

Schedule Relative Risk:

Bounding Relative Risk:
C Conventional construction projects of this magnitude would typically have more than one death occurring during the activity

B Possibly $>10 \$ \mathrm{M}$ due to schedule slippage

B Expect delays of many months to investigate accident

B Expected on projects of this magnitude, but actively working to reduce likelihood (e.g., NIF Project Site Safety Program)

II

I

I

II (ES\&H risk is bounding) 
19. Risk of regulation or permit violation during construction.

ES\&H Consequence:

Cost Consequence:

Schedule Consequence:

Likelihood:

ES\&H Relative Risk:

Cost Relative Risk:

Schedule Relative Risk:

Bounding Relative Risk:
B Expected to be minor, but could result in significant injury

A Possibly 5-10\$M due to schedule slippage, fines

A Minor delays to investigate violation

B Large project

I

I

I

I

20. Risk of severe natural phenomena occurring during construction.

ES\&H Consequence:

Cost Consequence:

Schedule Consequence:

Likelihood:

Cost Relative Risk:

Schedule Relative Risk:

Bounding Relative Risk:
B Could result in severe injury; small spills may occur, minor worker injuries would be more typical

B $>10 \$ \mathrm{M}$ from schedule slippage, may have to repair some parts of the facility that were already constructed

A Maybe up to a few months to recover at most

B Severe earthquakes (e.g., like Loma Prieta) infrequent

21. Risk of delay in completing Management Prestart Reviews at points in the commissioning sequence introducing significant new risk.

Cost Consequence:

Schedule Consequence:

Likelihood:

Cost Relative Risk:

Schedule Relative Risk:

Bounding Relative Risk:
A Potentially $<10 \$ \mathrm{M}$ due to schedule delays

A Could result in weeks to months delay

B Early planning for MPRs

I

I

I 
22. Risk of shortfalls in the NIF Demonstration Program resources to commission and start-up NIF.

Cost Consequence:

B $\quad 10-100 \$ M$ due to schedule delays

Schedule Consequence:

B Could result in many months of delays until ICF program works it into their budget

Likelihood:

B Future budgets uncertain, but NIF has high priority, Nova operations decreasing

Cost Relative Risk:

I

Schedule Relative Risk: I

Bounding Relative Risk: I

23. Risk of performance shortfall in the NIF laser systems that affect the ability to achieve performance requirements.

Performance Consequence:

Cost Consequence:

Schedule Consequence:

Likelihood:

Performance Relative Risk:

Cost Relative Risk:

Schedule Relative Risk:

Bounding Relative Risk:
C Facility may not be able to operate at any useful level; facility mission may be compromised

C potentially very high, if expend $>2.2 \$ B$ and facility doesn't perform, plus possible additional costs to retrofit

C Could be many years to redesign and install

A New technology, but some experience with Beamlet and NEL, modeling, prototyping, etc. (could also have more likely scenarios, but impacts will be less; risk is the same)

24. Risk of a change in the regulatory agency (DOE to other).

Cost Consequence:

Schedule Consequence

Likelihood

Cost Relative Risk:
A $5-10 \$ M$ due to schedule delays

A Possibly as much as a few months delay B

I 
Schedule Relative Risk:

Bounding Relative Risk

25. Risk of Cost Growth.

Cost Consequence:

Likelihood:

Cost Relative Risk:

Bounding Relative Risk:

26. Risk of delays in the Acquisition Executive approving Critical Decision 4.

Cost Consequence:

Schedule Consequence:

Likelihood:

Cost Relative Risk:

Schedule Relative Risk:

Bounding Relative Risk:
B $\quad 10-100 \$ M$ potentially from costs for change orders, legal costs, commodity price increases

II

II (Cost risk is bounding)

27. Risk of data loss or compromise.

Cost Consequence:

Schedule Consequence:

Likelihood:

Cost Relative Risk:

Schedule Relative Risk:

Bounding Relative Risk:
B $>10 \$ M$ due to schedule slippage

B Possibly few months delay

A Most of Project already handed over to Program
I

I

I

In cases where the different types of consequences lead to different Relative Risk values, the highest Relative Risk value is noted in Table 1. 


\section{APPENDIX B \\ Initial $(2 / 97,4 / 98)$ NIF Risk Elements}

The likelihood, consequence, and relative risk of NIF risk elements and associated mitigation efforts were first developed in February 1997 to support CD3. These were updated in April of 1998. They are included in this appendix to provide a comparative record. 
Table 1. Likelihood, consequences, and relative risk of NIF Risk Elements and associated mitigation measures (updated 4/3/98).

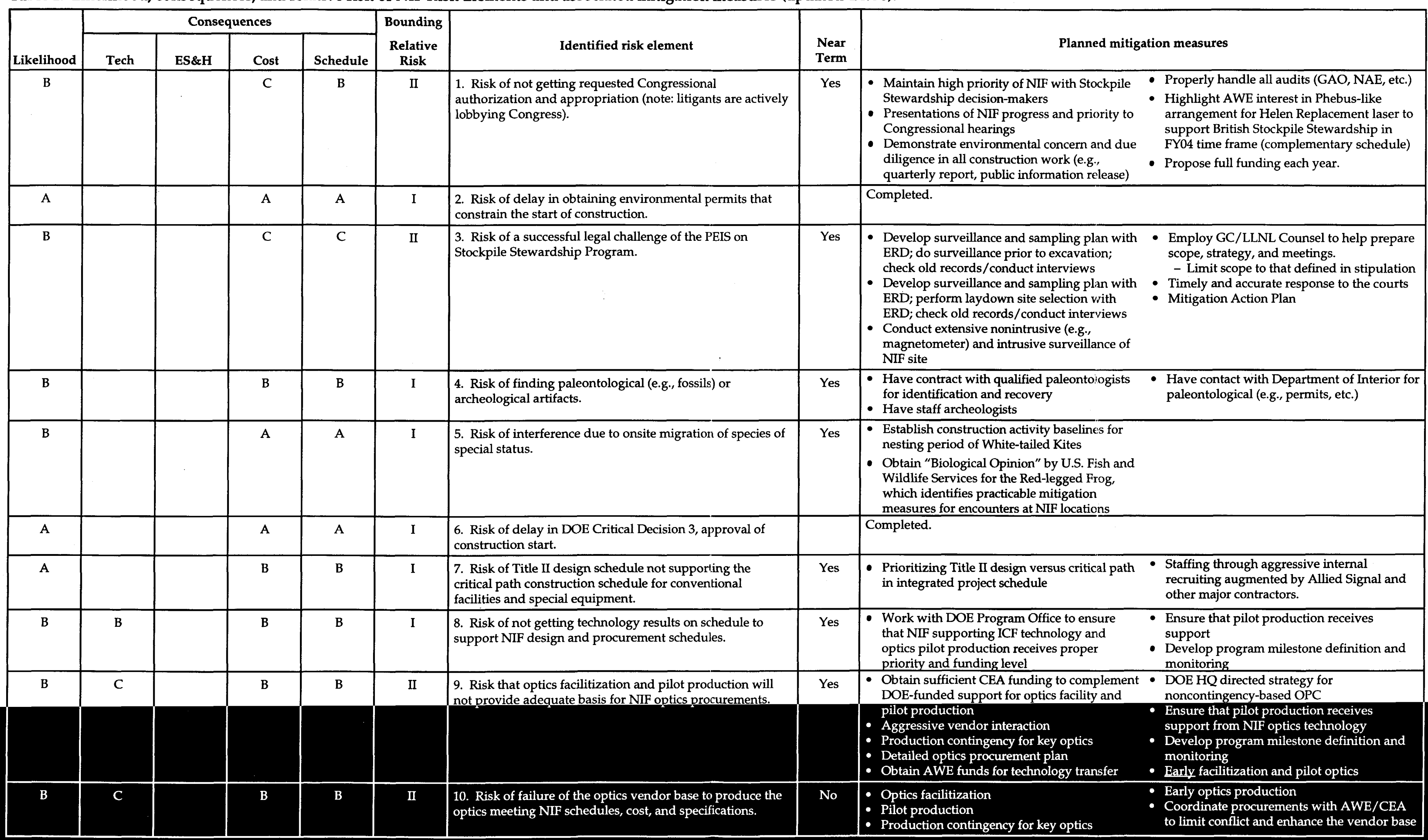


Table 1. Continued.

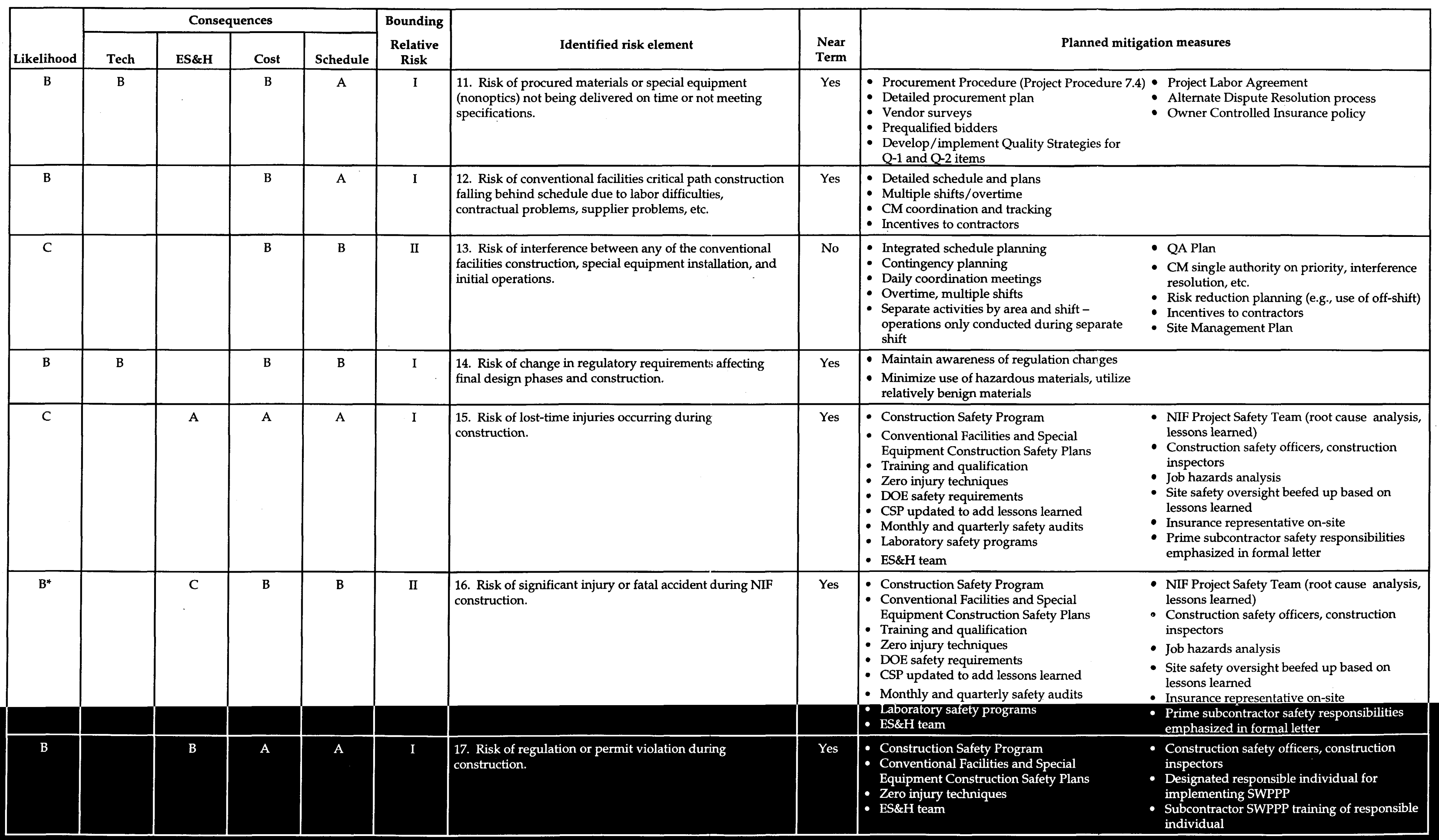


Table 1. Continued.

\begin{tabular}{|c|c|c|c|c|c|c|c|c|c|}
\hline \multirow[b]{2}{*}{ Likelihood } & \multicolumn{4}{|c|}{ Consequences } & \multirow{2}{*}{\begin{tabular}{c|} 
Bounding \\
$\begin{array}{c}\text { Relative } \\
\text { Risk }\end{array}$ \\
\end{tabular}} & \multirow[b]{2}{*}{ Identified risk element } & \multirow[b]{2}{*}{$\begin{array}{l}\text { Near } \\
\text { Term }\end{array}$} & \multirow{2}{*}{\multicolumn{2}{|c|}{ Planned mitigation measures }} \\
\hline & Tech & ES\&H & Cost & Schedule & & & & & \\
\hline B & & B & $B$ & $\mathrm{~A}$ & I & $\begin{array}{l}\text { 18. Risk of severe natural phenomena occurring during } \\
\text { construction. }\end{array}$ & Yes & $\begin{array}{l}\text { - Biological opinion and arroyo clearing to } \\
\text { reduce flood hazard (El Niño) } \\
\text { - Planning for El Niño (e.g., diking, use of soil } \\
\text { treatments to minimize water penetration) } \\
\text { - Emergency Plan } \\
\text { - Training }\end{array}$ & $\begin{array}{l}\text { - NIF OPR Change Control Board (ICF/NIF } \\
\text { Programs) to control cost/schedule } \\
\text { - Prepare detailed start-up plans } \\
\text { - Obtain AWE funds for technology } \\
\text { transfer/AWE staff for start-up in } \\
\text { preparation for Helen Replacement laser } \\
\text { - Perform formal acceptance test procedures }\end{array}$ \\
\hline B & & & B & B & I & $\begin{array}{l}\text { 19. Risk of delay in completing the ORR for the first laser } \\
\text { bundle (BU31) and handing it over to the operating ICF } \\
\text { Program. }\end{array}$ & No & $\begin{array}{l}\text { - Project/Program focus } \\
\text { ORR plan prepared early on } \\
\text { - Training }\end{array}$ & \\
\hline B & & & B & B & I & $\begin{array}{l}\text { 20. Risk of shortfalls in the ICF Program resources to } \\
\text { operate the NIF first bundle and subsequent laser clusters. }\end{array}$ & No & $\begin{array}{l}\text { - High priority of Stockpile Stewardship } \\
\text { Program in DP/commitment of LLNL } \\
\text { Laboratory Director } \\
\text { - High priority of NIF operation } \\
\text { - Phasing of Nova shutdown and NIF } \\
\text { activation } \\
\text { - Level of funding may be reduced but balance } \\
\text { would be maintained to support the ICF } \\
\text { program }\end{array}$ & \\
\hline B & & B & $c$ & C & II & $\begin{array}{l}\text { 21. Risk of severe accident during first laser bundle start- } \\
\text { up and subsequent operations. }\end{array}$ & No & $\begin{array}{l}\text { - Detailed hazards analysis in FSAR } \\
\text { - Operational Safety Requirements set limits of } \\
\text { operation } \\
\text { - Acceptance test procedures } \\
\text { - Use of experienced Nova personnel for } \\
\text { facility operation }\end{array}$ & $\begin{array}{l}\text { - Detailed FSP and OSPs before start-up } \\
\text { activities } \\
\text { - ORR will be performed } \\
\text { - Consideration of lessons learned (e.g., } \\
\text { Beamlet vacuum barrier implosion) }\end{array}$ \\
\hline B & C & & C & c & II & $\begin{array}{l}\text { 22. Risk of performance shortfall in the NIF special } \\
\text { equipment systems that affect the ability to achieve } \\
\text { technical requirements. }\end{array}$ & No & $\begin{array}{l}\text { - Off-line laboratory (e.g., AMPLAB) results } \\
\text { Beamlet results } \\
\text { QA Plan including quality levels } \\
\text { - Aggressive prototyping program } \\
\text { Develop and implement Quality Strategies } \\
\text { that identify areas for augmented } \\
\text { specification or work interactions for critical } \\
\text { items }\end{array}$ & $\begin{array}{l}\text { - Technology development/prototyping results } \\
\text { - Lessons learned from first laser bundle } \\
\text { - Formal design reviews } \\
\text { - Perform formal acceptance test procedures }\end{array}$ \\
\hline B & & & A & A & I & $\begin{array}{l}\text { 23. Risk of a change in the regulatory agency (DOE to } \\
\text { NRC or other). }\end{array}$ & No & $\begin{array}{l}\text { - Actively following discussions on the subject } \\
\text { - If regulatory agency changes, will discuss } \\
\text { requirements with them immediately, and } \\
\text { develop a plan }\end{array}$ & - \\
\hline B & & B & C & B & II & $\begin{array}{l}\text { 24. Risk from introduction of new hazardous materials in } \\
\text { future NIF experiments. }\end{array}$ & No & $\begin{array}{l}\text { - DOE has announced that they have made no } \\
\text { decision on fissile materials or lithium }\end{array}$ & $\begin{array}{l}\text { - DOE has made only one decision to add } \\
\text { material:uranium-238, depleted_uxanium in }\end{array}$ \\
\hline & & & & & & & & $\begin{array}{l}\text { hydride } \\
\text { DOE commits to prepare new NEPA and } \\
\text { safety evaluation prior to adding hazardous } \\
\text { material }\end{array}$ & $\begin{array}{l}\text { nonyield, subgram tests } \\
\text { - Safety analysis reports will be prepared for } \\
\text { any new hazardous materials }\end{array}$ \\
\hline
\end{tabular}




\begin{tabular}{|c|c|c|c|c|c|c|c|}
\hline C & A & A & I & 25. Risk of cost growth. & Yes & $\begin{array}{l}\text { - Contingency available } \\
\text { - Prequalification of vendors } \\
\text { - Minimize change orders } \\
\text { - Monitor markets } \\
\text { - Industry cost estimates based on conceptual } \\
\text { and Title I designs }\end{array}$ & $\begin{array}{l}\text { - Plan of action, describing proposed actions to } \\
\text { eliminate or ameliorate cost growth } \\
\text { - Maintain close contact with vendors } \\
\text { - Options for purchasing te. .o. quantity vs time, } \\
\text { - fabrication methods, etc. } \\
\text { - cost reduction efforts focusing on designing } \\
\text { to cost and limiting cost growth }\end{array}$ \\
\hline A & A & A & I & $\begin{array}{l}\text { 26. Risk of delays in the Acquisition Executive approving } \\
\text { CD } 4 \text {. }\end{array}$ & No & $\begin{array}{l}\text { - Majority of project already turned over by } \\
\text { CD4 } \\
\text { - Experience basis of } ~ 33 \text { years of operation } \\
\text { prior to CD4 }\end{array}$ & - Conservative design \\
\hline
\end{tabular}




\begin{tabular}{|c|c|c|c|c|c|c|c|c|}
\hline \multirow[b]{2}{*}{ Likelihood } & \multicolumn{4}{|c|}{ Consequences } & \multirow{2}{*}{\begin{tabular}{c|c}
$\begin{array}{c}\text { Bounding } \\
\text { Relative } \\
\text { Risk }\end{array}$ \\
\end{tabular}} & \multirow[b]{2}{*}{ Identified risk element } & \multirow{2}{*}{\multicolumn{2}{|c|}{ Planned mitigation measures }} \\
\hline & Tech & ES\&H & Cost & Schedule & & & & \\
\hline B & & & $\mathrm{C}$ & B & II & $\begin{array}{l}\text { 1. Risk of not getting Congressional required budget authorization } \\
\text { and appropriation. }\end{array}$ & $\begin{array}{l}\text { - Maintaining high priority of NIF with Stockpi } \\
\text { - Proposed full Project funding }\end{array}$ & Stewardship decision-makers \\
\hline A & & & B & A & I & $\begin{array}{l}\text { 2. Risk of delay in obtaining environmental pernits that constrain the } \\
\text { start of construction. }\end{array}$ & $\begin{array}{l}\text { - Permits submitted to regulatory agencies } \\
\text { Permits well prepared by experienced } \\
\text { preparers and internally reviewed }\end{array}$ & - Follow-up with regulatory agencies \\
\hline B & & & C & $\mathrm{B}$ & II & $\begin{array}{l}\text { 3. Risk of a successful legal challenge on the PEIS on Stockpile } \\
\text { Stewardship and Management. }\end{array}$ & $\begin{array}{l}\text { - PEIS reviewed and revised by DOE GC and } \\
\text { DOE EH to fully satisfy NEPA, weaknesses } \\
\text { fortified } \\
\text { - NEPA reviewed by GC/EH with Secretary } \\
\text { on two occasions prior to ROD }\end{array}$ & $\begin{array}{l}\text { - Planned response to inquiries by potential } \\
\text { litigants } \\
\text { Litigation defense strategy to be developed if } \\
\text { sued }\end{array}$ \\
\hline A & & & $\mathrm{A}$ & A & $\mathrm{I}$ & $\begin{array}{l}\text { 4. Risk of delay in DOE Critical Decision 3, approval of construction } \\
\text { start. }\end{array}$ & $\begin{array}{l}\text { - ROD published } \\
\text { Action memo prepared } \\
\text { Delegation to ASDP } \\
\text { - ASDP kept well informed } \\
\text { Construction plan in place }\end{array}$ & $\begin{array}{l}\text { - Permits submitted } \\
\text { Published documents for DOE to make } \\
\text { decision, e.g., PSAR approved, PEP approved } \\
\text { Bids complete for first construction packages } \\
\text { - All supporting documentation completed }\end{array}$ \\
\hline A & & & B & B & $I$ & $\begin{array}{l}\text { 5. Risk of Title II design schedule not supporting the critical path } \\
\text { construction schedule for conventional facilities and special } \\
\text { equipment. }\end{array}$ & $\begin{array}{l}\text { - Focused special equipment interface } \\
\text { definition } \\
\text { - Detailed Title I and II design plans }\end{array}$ & $\begin{array}{l}\text { - Overtime and multiple shift } \\
\text { Acceleration of Title II S.E. design impacting } \\
\text { construction }\end{array}$ \\
\hline B & B & & $B$ & $B$ & I & $\begin{array}{l}\text { 6. Risk of not getting technology results on schedule to support NIF } \\
\text { design and procurement. }\end{array}$ & $\begin{array}{l}\text { - Integrated NIF project/program } \\
\text { - Redistribution of budgets to meet priorities }\end{array}$ & $\begin{array}{l}\text { - Milestone definition and monitoring } \\
\text { QA Plan }\end{array}$ \\
\hline B & $\mathrm{C}$ & & B & $B$ & II & $\begin{array}{l}\text { 7. Risk that optics facilitization and pilot production will not provide } \\
\text { adequate basis for NIF optics procurements. }\end{array}$ & $\begin{array}{l}\text { - Aggressive vendor interaction } \\
\text { Production contingency for key optics }\end{array}$ & $\begin{array}{l}\text { - Detailed optics procurement plan } \\
\text { Early facilitization and pilot optics }\end{array}$ \\
\hline$B$ & B & & B & B & $I$ & $\begin{array}{l}\text { 8. Risk of failure of the limited optics vendor base to produce all of } \\
\text { the optics required to meeting NIF schedules, cost, and specifications. }\end{array}$ & $\begin{array}{l}\text { - Optics facilitization } \\
\text { Pilot production }\end{array}$ & $\begin{array}{l}\text { - Production contingency for key optics } \\
\text { - Early optics production }\end{array}$ \\
\hline$B$ & B & & A & A & I & $\begin{array}{l}\text { 9. Risk of procured materials or special equipment (non-optics) not } \\
\text { being delivered on time or not meeting specifications. }\end{array}$ & $\begin{array}{l}\text { - Vendor surveys } \\
\text { - Prequalified bidders } \\
\text { - Requirement specifications }\end{array}$ & $\begin{array}{l}\text { - ICDs } \\
\text { - Best-value procurement selection method }\end{array}$ \\
\hline$B$ & & & B & A & I & $\begin{array}{l}\text { 10. Risk of conventional facilities critical path construction falling } \\
\text { behind schedule due to labor difficulties, contractual problems, } \\
\text { supplier problems, etc. }\end{array}$ & $\begin{array}{l}\text { Detailed schedule and plans } \\
\text { Multiple shifts/overtime } \\
\text { CM coordination and tracking } \\
\text { - Incentives to contractors }\end{array}$ & $\begin{array}{l}\text { - Project Labor Agreement } \\
\text { - Alternate Dispute Resolution process } \\
\text { - Owner Controlled Insurance policy }\end{array}$ \\
\hline$B$ & & & B & $B$ & I & $\begin{array}{l}\text { 11. Risk of interference between any of conventional facilities } \\
\text { construction, special equipment installation, and initial operations. }\end{array}$ & $\begin{array}{l}\text { - Integrated schedule planning } \\
\text { - Contingency planning } \\
\text { Daily coordination meetings }\end{array}$ & $\begin{array}{l}\text { - CM single authority on priority, interference } \\
\text { resolution, etc. } \\
\text { - Risk reduction planning (eg, use.of off-shift) }\end{array}$ \\
\hline & & & & & & & $\begin{array}{l}\text { - Overtime, multiple shifts } \\
\text { QA Plan }\end{array}$ & $\begin{array}{l}\text { - Incentives to contractors } \\
\text { Plan }\end{array}$ \\
\hline
\end{tabular}




\begin{tabular}{|c|c|c|c|c|c|c|c|c|}
\hline \multirow[b]{2}{*}{ Likelihood } & \multicolumn{4}{|c|}{ Consequences } & \multirow{2}{*}{$\begin{array}{c}\text { Bounding } \\
\text { Relative } \\
\text { Risk }\end{array}$} & \multirow[b]{2}{*}{ Identified risk element } & \multirow{2}{*}{\multicolumn{2}{|c|}{ Planned mitigation measures }} \\
\hline & Tech & ES\&H & Cost & Schedule & & & & \\
\hline c & & A & A & A & I & 12. Risk of lost-time injuries occurring during construction. & $\begin{array}{l}\text { - Conventional Facilities and Safety Equipment } \\
\text { Construction Safety Program and Plans } \\
\text { - Training } \\
\text { - Zero accident policy } \\
\text { - DOE safety requirements }\end{array}$ & $\begin{array}{l}\text { - ES\&H team } \\
\text { Construction safety officers, construction } \\
\text { inspectors } \\
\text { - Job hazards analysis }\end{array}$ \\
\hline $\mathrm{B}^{*}$ & & $\mathrm{C}$ & B & B & II & 13. Risk of significant injury or fatal accident during NIF construction. & $\begin{array}{l}\text { - Construction safety program } \\
\text { Conventional facilities and special equipment } \\
\text { construction safety plans } \\
\text { - Zero accident policy } \\
\text { - Laboratory safety programs } \\
\text { Training }\end{array}$ & $\begin{array}{l}\text { - DOE safety requirements } \\
\text { ES\&H team } \\
\text { - Construction safety officers, construction } \\
\text { inspectors } \\
\text { Job hazards analysis }\end{array}$ \\
\hline B & & B & B & A & I & 14. Risk of regulation or permit violation during construction. & $\begin{array}{l}\text { - Construction Safety Program } \\
\text { - Conventional facilities and special equipment } \\
\text { construction safety plans } \\
\text { - Zero injury techniques } \\
\text { - ES\&H team }\end{array}$ & $\begin{array}{l}\text { - Construction safety officers, construction } \\
\text { inspectors } \\
\text { - Designated responsible individual for } \\
\text { implementing SWPPP }\end{array}$ \\
\hline B & & B & B & A & I & 15. Risk of severe natural phenomena occurring during construction. & $\begin{array}{l}\text { - Emergency Plan } \\
\text { - Training } \\
\text { - Mitigation Action Plan }\end{array}$ & $\begin{array}{l}\text { - Quality levels } \\
\text { - Tie downs (for seismic, wind, flooding) }\end{array}$ \\
\hline B & & & B & B & $\mathbf{I}$ & $\begin{array}{l}\text { 17. Risk of shortfalls in the ICF Program resources to operate the NIF } \\
\text { first bundle and to activate the subsequent laser llusters. }\end{array}$ & $\begin{array}{l}\text { - High priority of Stockpile Stewardship } \\
\text { Program in DP/commitment of LLNL } \\
\text { Laboratory Director } \\
\text { - High priority of NIF operation } \\
\text { - Phasing of Nova shutdown and NIF } \\
\text { activation }\end{array}$ & $\begin{array}{l}\text { - Level of funding may be reduced but balance } \\
\text { would be maintained to support the ICF } \\
\text { program }\end{array}$ \\
\hline B & $\mathrm{B}$ to $\mathrm{C}$ & & B to $C$ & B to C & I to II & $\begin{array}{l}\text { 18. Risk of performance shortfall in the NIF special equipment } \\
\text { systems that affect the ability to achieve technical requirements. }\end{array}$ & $\begin{array}{l}\text { - Off-line laboratory (e.g., AMPLAB) result: } \\
\text { - Beamlet results } \\
\text { - QA Plan including quality levels }\end{array}$ & $\begin{array}{l}\text { - Technology development/prototyping results } \\
\text { - Lessons learned from first laser bundle } \\
\text { - Formal design reviews }\end{array}$ \\
\hline c & & & A & A & I & 19. Risk of a change in the regulatory agency (DOE to NRC or other). & $\begin{array}{l}\text { - Actively following discussions on the subject } \\
\text { - If regulatory agency changes, will discuss } \\
\text { requirements with them immediately, and } \\
\text { develop a plan }\end{array}$ & \\
\hline & & & & & & $\begin{array}{l}\text { 20. Risk of delays in the Acquisition Executive approving Critical } \\
\text { Decision } 4 \text {. }\end{array}$ & $\begin{array}{l}\text { - Majority of project already turned over by } \\
\text { - ED4 } \\
\text { prior to CD4 }\end{array}$ & - AE kept informed about NIF \\
\hline
\end{tabular}

